\title{
NEW GENUS OF DORUDONTINE ARCHAEOCETE (CETACEA) FROM THE MIDDLE-TO-LATE EOCENE OF SOUTH CAROLINA
}

\author{
MARK D. UHEN \\ Cranbrook Institute of Science, \\ 39221 N. Woodward Avenue, \\ P. O. Box 801, \\ Bloomfield Hills, Michigan 48303-0801, U.S.A. \\ E-mail: muhen@cranbrook.edu \\ Philip D. Gingerich \\ University of Michigan, \\ Museum of Paleontology, \\ 1109 Geddes, \\ Ann Arbor, Michigan 48109, U.S.A.
}

\begin{abstract}
A new archaeocete whale from the late middle or early late Eocene of South Carolina, Chrysocetus bealyorum gen. et sp. nov., is described on the basis of a single subadult specimen. This individual includes: a partial skull; hyoid apparatus; lower jaws; teeth; all cervical, some thoracic and some lumbar vertebrae; ribs and sternum; left forelimb elements; and pelves. The specimen includes portions of much of the body, but while some of the bones are fairly complete, others are damaged, particularly the skull. The pelves resemble those of Basilosaurus, documenting a similar stage of hind limb reduction in dorudontines and suggesting that Chrysocetus was not able to support its body on land. The acetabulum for articulation of the femur is well formed and indicates that the hip joint was functional. Chrysocetus is distinguishable from other described dorudontines based on body size, characteristics of the teeth, and forelimb elements. Absence of deciduous teeth in a subadult individual of Cbrysocetus may be indicative of an early stage of the evolution of monophyodonty.
\end{abstract}

Key words: Archaeoceti, Basilosauridae, Dorudontinae, Eocene, Cross Formation, innominate, pelvis, hind limb, monophyodonty.

The Eocene Atlantic Coastal Plain deposits of North America have yielded a specimen of a new genus of dorudontine archaeocete that includes the first example of a dorudontine pelvis, as well as a dental eruption pattern not 
previously known from archaeocete cetaceans. This specimen is of particular importance to the study of the transition from archaeocete cetaceans to the modern suborders, Odontoceti and Mysticeti.

Many recent fossil discoveries have led to greater understanding of locomotion in whales during the transition from their cursorial terrestrial ancestors to their swimming aquatic descendants (Gingerich et al. 1990, 1994, 1995; Thewissen et al. 1994; Hulbert et al. 1998). Although pelves and femora have been known from the large archaeocete Basilosaurus since the early twentieth century (Lucas 1900, Gidley 1913), no more was known about the hindlimb of archaeocetes until the discovery of the feet of Basilosaurus demonstrated the extent of hindlimb reduction at this stage of evolution. The hind limbs of Basilosaurus are very reduced and not capable of supporting the body on land but are still functional in other respects (Gingerich et al. 1990). Very little has been known about the hind limbs of dorudontine archaeocetes that were contemporaneous with Basilosaurus in both North America and Egypt (Gingerich et al. 1990). It is important to characterize the hind limbs of this group since they are thought to be ancestral to all modern cetaceans (Barnes and Mitchell 1978, Barnes et al. 1985, Fordyce and Barnes 1994, Uhen 1998).

This new specimen also appears to be a juvenile based on the epiphyseal fusion state of the skeleton, but it has teeth that have all of the features of adult archaeocete teeth rather than deciduous teeth. This suggests that either this individual replaced its deciduous teeth very early in its ontogeny or it never erupted deciduous teeth. In either case, this documents an important stage in the development of the monophyodonty seen in modern cetaceans.

Abbreviations used in the text and figure captions are as follows: ALMNH, Alabama Museum of Natural History, Tuscaloosa, Alabama; SCSM, South Carolina State Museum, Columbia, South Carolina; UM, University of Michigan Museum of Paleontology, Ann Arbor, Michigan; USNM, United States National Museum of Natural History, Washington, DC.

\section{SySTEMATICS}

Mirorder Cete Linné, 1758 sensu McKenna and Bell 1997

Order Cetacea Brisson, 1762

Suborder Archaeoceti Flower, 1883

Family Basilosauridae Cope, 1868 sensu Barnes and Mitchell 1978

Subfamily Dorudontinae Miller, 1923 sensu Barnes and Mitchell 1978

Chrysocetus, new genus

TYPE SPECIES

Chrysocetus bealyorum $\mathrm{n} . \mathrm{sp}$.

Diagnosis

Same as for the species. 


\section{ETYMOLOGY}

The generic name Chrysocetus is derived from the Greek cbrysous, meaning golden, and ketos (masc.), meaning whale. This is in reference to the rich, gold color of the bones of the type specimen of Cbrysocetus bealyorum.

\section{Discussion}

Chrysocetus is assigned to the archaeocete family Basilosauridae based on the presence of multiple accessory denticles on the premolars, the reduced hind limb, the similarity of cranial elements to those of other basilosaurids, and its stratigraphic position. Basilosaurids also share the loss of the $\mathbf{M}^{3}$ and the presence of two roots on the upper molars (Miller 1923, Kellogg 1936), but these characters could not be assessed for $C$. healyorum as no molars are preserved with the specimen. $C$. healyorum is assigned to the subfamily Dorudontinae based on its small size and the presence of thoracic and lumbar vertebral bodies which are approximately as long as they are wide or tall (Uhen 1998). In contrast, members of the subfamily Basilosaurinae have elongate posterior thoracic, lumbar, and anterior caudal vertebral bodies and large body size (Kellogg 1936, Barnes and Mitchell 1978). C. bealyorum is placed in a new genus rather than the relatively common North American genus Zygorbiza because $C$. bealyorum lacks well-developed denticles on the cingula of the upper premolars, a characteristic feature of Zygorbiza (Köhler and Fordyce 1997).

\section{Chrysocetus bealyorum, new species}

\section{HoLOTYPE}

South Carolina State Museum (SCSM) 87.195. Skeleton of a juvenile individual which includes a partial skull; hyoid apparatus; lower jaws; ten teeth (plus additional fragments); seven cervical, eleven thoracic, and three lumbar vertebrae; ribs and sternum; left forelimb elements; and portions of the both pelves.

\section{Diagnosis}

Chrysocetus bealyorum has features of Dorudontinae (particularly vertebral bodies that lack elongation seen in members of the Basilosauridae) but differs from other Dorudontines in having smooth enamel and lacking vertically oriented ornamentation on the upper premolars. In addition, the premolars are more gracile than those of Dorudon, and the upper premolars lack crenulations on the mesial and distal cingula like those of Zygorbiza (Kellogg 1936; see Fig. 1). Based on comparable skeletal elements, $C$. bealyorum was larger than Sagbacetus osiris and smaller than Pontogeneus bracbyspondylus. 



Figure 1. Right upper third premolars of A, Dorudon atrox (UM 101222); B, Chrysocetus healyorum (SCSM 87.195); and C, Zygorbiza kochii (ALMNH PV2000.1.1), in lingual view. Image in $C$ photographically reversed and tooth whitened with aluminum chloride. Note $\mathrm{P}^{3}$ of $C$. bealyorum very gracile and lacks ornamentation seen in $D$. atrox and $Z$. kochii. Slight irregular texture of enamel on premolar of $Z$. kochii due to damage done by recent roots. Scale bar equals $5 \mathrm{~cm}$.

\section{ETYMOLOGY}

The specific epithet, healyorum, is in honor of Craig and Alice Healy of West Columbia, South Carolina, who discovered the holotype specimen.

\section{HORIZON AND LOCALITY}

Santee Cement Quarry in Holly Hill, Orangeburg County, South Carolina $\left(33^{\circ} 19^{\prime} 30^{\prime \prime} \mathrm{N}, 80^{\circ} 24^{\prime} 49^{\prime \prime} \mathrm{W}\right)$. The Santee Cement Quarry was formerly known as the Santee Portland Quarry. The late Bartonian-to-early Priabonian (late middle to early late Eocene) Cross Formation is exposed in the quarry (Baum et al. 1980) and is composed of molluscan biomicrudites (Powell and Baum 1982). The early Bartonian (middle Eocene) upper Santee Formation, which is composed of bryozoan biosparrudites and biomicrudites, should occur stratigraphically below the Cross Formation, but it has not been reported to be exposed in the quarry. Matrix associated with the type specimen lacks macrofossils and calcareous nannofossils, precluding their use for an age assignment, but the matrix also lacks quartz sand, which suggests that it is from the Cross Formation. ${ }^{1}$

\section{AGE}

The Cross Formation is late Bartonian to early Priabonian (late middle to early late Eocene) in age (Harris et al. 1993), which is calibrated to around 38.5 to 36.0 MYA (Berggren et al. 1995).

${ }^{1}$ Personal communication from Richard Laws. 
Table 1. Measurements of teeth of Chrysocetus bealyorum. All measurements in $\mathrm{mm}$ and accurate to nearest tenth of $\mathrm{mm}$ (except for $\mathrm{LP}^{4}$ which is slightly damaged). Dashes indicate measurement could not be taken due to breakage. Number of denticles on mesial and distal margins of each tooth listed.

\begin{tabular}{lccccc}
\hline Tooth & Length & Width & Height & $\begin{array}{c}\text { Mesial } \\
\text { denticles }\end{array}$ & $\begin{array}{c}\text { Distal } \\
\text { denticles }\end{array}$ \\
\hline $\mathrm{LI}^{1}$ & 15.6 & 11.1 & - & 0 & 0 \\
$\mathrm{RI}^{1}$ & 15.8 & 10.5 & 23.9 & 0 & 0 \\
$\mathrm{LI}^{3}$ & 19.5 & 12.4 & 27.3 & 0 & 0 \\
$\mathrm{LP}^{1}$ & 22.2 & 11.7 & 26.4 & 0 & 1 \\
$\mathrm{RP}^{1}$ & 22.1 & 12.3 & - & 0 & 1 \\
$\mathrm{LP}^{2}$ & - & 12.1 & 27.8 & 3 & 3 \\
$\mathrm{RP}^{2}$ & 41.6 & 12.0 & 29.0 & 3 & 3 \\
$\mathrm{LP}^{3}$ & 46.7 & 13.2 & 29.0 & 4 & 4 \\
$\mathrm{LP}^{4}$ & 38 & 11 & - & 3 & 3 \\
$\mathrm{RP}_{3}$ & 49.3 & 11.8 & 32.0 & 5 & 5 \\
\hline
\end{tabular}

\section{DESCRIPTION}

Teeth-Ten teeth are known from Chrysocetus bealyorum, along with additional partial crowns. Left and right $\mathrm{I}^{1}$, as well as left $\mathrm{I}^{3}$, are preserved in the premaxillae, and other teeth were recovered separately. Loose teeth were identified based on comparisons with other basilosaurid teeth. Questionably assigned teeth are indicated by a question mark. All teeth have closed roots and have, at most, light apical wear on their cusps. Teeth of $C$. bealyorum are basically similar to those of other basilosaurids, with exceptions noted below. Measurements of the teeth are listed in Table 1.

Incisors are all single-rooted caniniform teeth (Fig. 2A). All curve distally and slightly lingually. All of the incisors have strong mesial carinae and moderately developed vertical striations on their lingual faces. Left and right $\mathrm{I}^{1}$ and left $\mathrm{I}^{3}$ are in place in the premaxillae. A number of loose teeth are probably lower incisors or possibly canines, although none can be positively identified.

A complete set $\left(\mathrm{P}^{1}\right.$ to $\left.\mathrm{P}^{4}\right)$ of left upper premolars is present (Fig. 3A). In addition, right $\mathrm{P}^{1}, \mathrm{P}^{2}$, and right $\mathrm{P}_{3(4)}$ (Fig. 3B) are also present. With the exception of $\mathrm{P}^{1}$, all of the upper premolars are double rooted, generally triangular in buccal view, and have multiple accessory denticles along their mesial and distal margins. The accessory denticles are larger on the distal margin than the denticles on the mesial margin of each tooth. $\mathrm{P}^{1}$ is much more caniniform, but differs from more mesial teeth in having a strong vertical groove on the buccal and lingual sides of the root, as well as a strong distal carina with a tiny cusp at the base. $\mathrm{P}^{2}$ is the most mesial double-rooted tooth in the upper jaw, is considerably larger than $\mathrm{P}^{1}$, and is slightly smaller than $\mathrm{P}^{3} . \mathrm{P}^{3}$ and $\mathrm{P}^{4}$ have lingually expanded posterior roots. The presumed $\mathrm{P}^{3}$ is considerably larger than the presumed $\mathrm{P}^{4}$. The upper premolars have moderately developed mesial and distal cingula, with additional crenulations weakly developed on the distal cingula.

The lower $\mathrm{P}_{3(4)}$ is the largest tooth recovered. It is presumed to be $\mathrm{P}_{3}$ 



Figure 2. Cranial sections of holotype of Chrysocetus bealyorum, SCSM 87.195. A, left premaxilla in lateral view. Note broken $\mathrm{I}^{1}, \mathrm{I}^{2}$ alveolus, and complete $\mathrm{I}^{3}$ in place in premaxilla. A, posterior skull in dorsal and B, lateral views. Note open sutures between frontals and parietals, as well as parietals and supraoccipital. Scale bar equals $10 \mathrm{~cm}$.

because it lacks lingual expansion of the posterior root of the upper premolars and $\mathrm{P}_{3}$ is the largest lower tooth in other dorudontines. The crown is tall and buccolingually compressed. Accessory denticles are tall and well separated from one another.

Skull-The skull of the type specimen of Chrysocetus healyorum was badly damaged during excavation, and large portions of the skull remain fragmentary or missing. The largest intact piece of skull includes the dorsal occipital region, the dorsal temporal region, and the medial frontal region (Fig. 2A, B). 

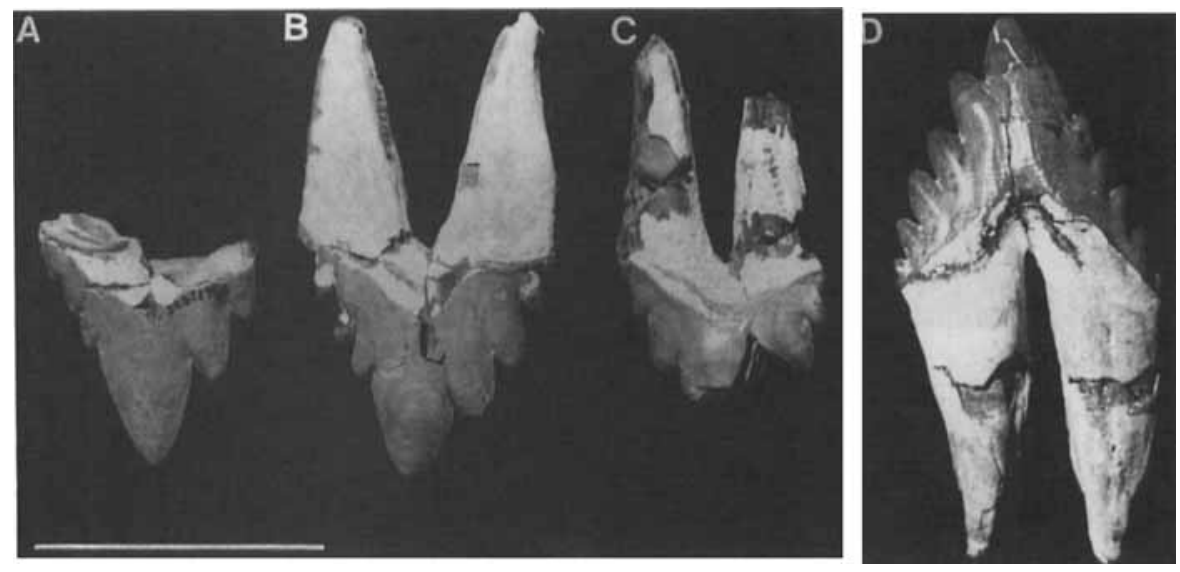

Figure 3. A, left upper premolars of holotype of Chrysocetus bealyorum, SCSM $87.195\left(\mathrm{P}^{2}-\mathrm{P}^{4}\right)$ in buccal view; $\mathrm{B}$, right lower $\mathrm{P}_{3(4) \text { ? }}$ in buccal view. Note high crowns of the teeth and that roots angle in towards midline of tooth. Scale bar equals $5 \mathrm{~cm}$.

Other large pieces include the left and right anterior premaxillae, right squamosal, left lacrimal, and left tympanic bulla.

The left anterior premaxilla contains the alveoli for $\mathrm{I}^{1}-\mathrm{I}^{3}$, while the right premaxilla is broken through the alveolus for $\mathrm{I}^{2}$. The vertical profile of the premaxilla tapers anteriorly, coming to a rounded end anterior to $\mathrm{I}^{1}$. The premaxilla is mediolaterally thickest at the $\mathrm{I}^{3}$ alveolus, and thins anteriorly. Each of the incisor alveoli are separated by approximately equal diastemata and are connected to one another via grooves in the premaxilla along their medial borders. Posterior to each alveolus are indentations of the premaxilla indicating the positions where next-most-posterior lower teeth met the premaxilla when the jaw was closed. The palatal surface of the premaxilla is flat, as is the medial surface. There is no evidence of fusion of the left and right premaxillae at least as far back as the $\mathrm{I}^{3}$ alveolus, indicating that they may have been separated by a grove or gap in life, as in other basilosaurids.

Frontals of the type specimen of Cbrysocetus bealyorum are badly broken (Fig. $2 A)$. The dorsal surface of the paired frontals shows that they were fused anteriorly but still separated posteriorly along the frontal suture, near the frontoparietal suture. The dorsal surface of the frontals is perforated with many tiny foramina. At the frontoparietal suture, the frontal projects farthest posterior along the midline, forming a curved suture with the anterior end of the parietal.

The parietal articulates with the frontal anteriorly and posteriorly with the supraoccipital at an open suture. The left and right parietals are partially fused sagittally, with a groove between the parietals on their anterior ends. There is no sign of an interparietal. The sagittal crest is somewhat convex in lateral view.

The relarively intact left lacrimal (Fig. 4A, B) is separate from the rest of the skull, indicating that it was not fused to adjacent bones. The lacrimal 

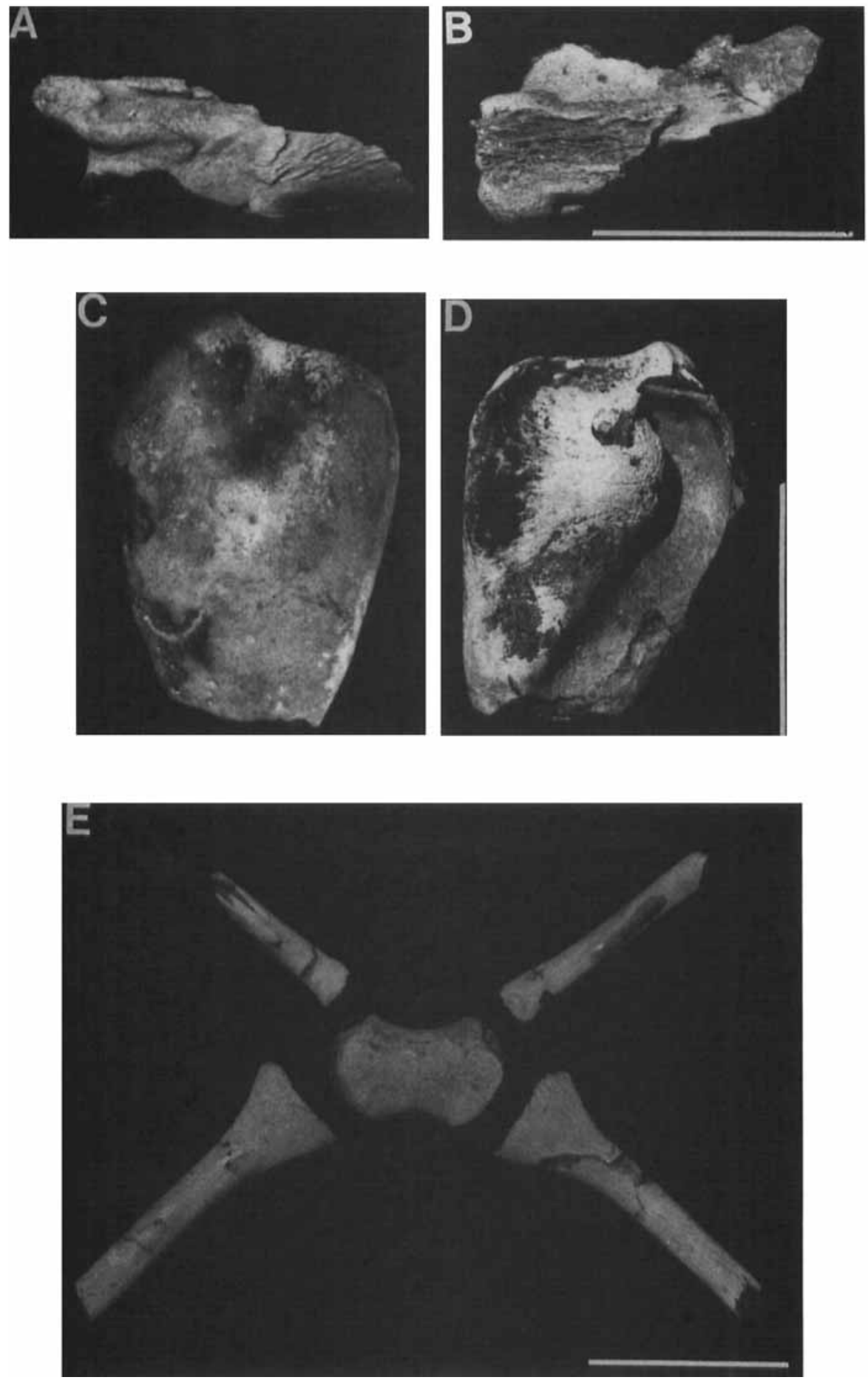
formed the anterior portion of the orbit when in place on the skull. The orbital or posterior surface of the lacrimal is concave, while the lateral surface presents three grooves leading from the orbit. The largest of these grooves is central, and the smaller dorsal and ventral groove join with the central groove and connect with the lacrimal canal.

On the left jugal, the anterior and posterior ends are broken and missing. The anteriormost end of the jugal is subtriangular in cross-section. At about its anteroposterior midpoint, the jugal becomes mediolaterally flattened and somewhat expanded dorsoventrally. The jugal then thins dorsoventrally towards the posterior end.

The supraoccipital articulates anterolaterally with the left and right parietals. The posterior face of the supraoccipital is deeply concave, with a low boss projecting posteriorly near its dorsal border. The supraoccipital is not elevated markedly above the level of the parietals. Most of the edges of the supraoccipital are damaged and missing, including its contacts with the exoccipitals.

A fragment of the right squamosal is preserved, but it is heavily damaged. None of the contacts with surrounding bones is preserved, and the glenoid fossa is missing as well. A small portion of the squamosal includes a section of the endocranial surface.

Much of the left auditory bulla is present with the specimen (Fig. 4C, D), although the sigmoid process is broken and missing and the posterior process is broken off. The bulla is large and typically basilosaurid in character. It has an overall squared-ovoid shape, with a depression on the ventral surfaces on the posterior end.

Mandible-Portions of both the left and right dentaries are preserved, although both are very fragmentary (Fig. 5). The right dentary is broken into two main pieces. The anterior fragment contains the posterior end of the $\mathrm{I}_{2}$ alveolus, complete $I_{3}, C_{1}$, and $P_{1}$ alveoli, and much of the alveolus for $P_{2}$. Alveoli for $I_{3}$ and $C_{1}$ show that these teeth had single roots. The alveolus for $P_{1}$ indicates a single root as well, but there is a vertical ridge of bone along the lateral border of the alveolus, indicating this tooth had a grooved root. There are two alveoli for $\mathrm{P}_{2}$. Shallow grooves connect adjacent alveoli along their medial margins and shallow depressions are present on the lateral surface of the dentary posterior to and ventral to each of the alveoli where the upper teeth met the dentary when the jaw was closed. Multiple mental foramina are present along the lateral face of the dentary.

The posterior fragment of the right dentary includes the articular condyle,

$\leftarrow$

Figure 4. Miscellaneous cranial elements of holotype of Chrysocetus healyorum, SCSM 87.195. A, right lacrimal in lateral and B, dorsal views. Note long projection that would have been sandwiched between maxilla and frontals when in articulation. $C$, left auditory bulla in ventral and $D$, dorsal views. Posterior up in $C$ and $D$. E, hyoid apparatus in ventral view. Note bow-tie shape of basihyoid and smaller stylohyoids (upper) in more cranial position relative to larger thyrohyoids (lower). Scale bar equals $10 \mathrm{~cm}$. 



Figure 5. Right dentary of holotype of Cbrysocetus bealyorum, SCSM 87.195. A, anterior end of dentary in dorsal view showing posterior end of $\mathrm{I}_{2}$ alveolus, complete $\mathrm{I}_{3}, \mathrm{C}_{1}$, and $\mathrm{P}_{1}$ alveoli, and much of alveolus for double-rooted $\mathrm{P}_{2}$. B, condyle of right dentary in posterodorsal view. $C$, posterior end of dentary in medial view. Note large mandibular foramen. D, posterior end of dentary in lateral view. Scale bar equals 10 $\mathrm{cm}$.

the mandibular foramen, and much of the mandibular canal. Most of the dorsal border of this fragment is destroyed, so individual alveoli are impossible to describe. The articular condyle (Fig. 5B) is unremarkable in form, generally triangular in dorsal outline, and the surface is convex. The mandibular foramen 
is very large (Fig. $5 \mathrm{C}$ ), as is the mandibular canal. While the coronoid process is broken on the right side, it is relatively complete on the left side. The coronoid crest rises steeply from the tooth row and then flattens out more posteriorly, making the whole coronoid process low and broad.

Hyoid apparatus - The hyoid apparatus of Chrysocetus healyorum is very similar to that of other described dorudontines (Uhen 1996). It consists of five elements: a central basihyal, paired stylohyals, and paired thyrohyals (Fig. 4E). The basihyal is bow-tie-shaped when viewed from the ventral or dorsal sides. The lateral margins of the basihyal are rough and spongy, indicating that the surface was covered with cartilage in life. This surface formed the articulation with the more cranial stylohyals and more caudal thyrohyals. The stylohyals are long, thin elements that join the hyoid apparatus to the base of the skull, probably at the paroccipital process. They are oval in cross-section. The proximal ends of the stylohyals are slightly expanded and concave. Both are missing their distal ends. The thyrohyals are much larger than the stylohyals, although they too have expanded, convex proximal ends, oval cross-sections, and broken distal ends.

Cervical vertebrae-Cervical vertebrae of Chrysocetus bealyorum are similar to those of other basilosaurids (Fig. 6A-H). The atlas ( $\mathrm{C} 1$ ) dorsal arch is perforated on both sides of the midline by large foramina for the first cervical nerve (Kellogg 1936). The axis (C2) has a tall and robust neural spine, unlike the other cervical vertebrae. The bodies of $\mathrm{C} 3-\mathrm{C} 7$ are somewhat compressed relative to those of protocetid archaeocetes, but cervical vertebrae are not fused to one another (Fig. 6H). Cervical vertebrae increase in size from $\mathrm{C} 3$ to $\mathrm{C} 7$ (see Table 2). C6 differs from the other cervicals in having very large parapophyses. The epiphyses of $\mathrm{C} 3-\mathrm{C} 7$ are attached to the vertebral bodies, but they are not fully fused to the bodies.

Thoracic vertebrae-Twelve thoracic vertebrae were recovered, and there were almost certainly more that were not recovered. Measurements of the vertebrae are listed in Table 2. Dorudon atrox is known to have had 17 (Uhen 1996) and Zygorbiza kocbii is thought to have had 15 thoracic vertebrae (Kellogg 1936). Thoracic vertebrae were arranged from cranial to caudal based on the size and shape of the vertebral bodies, the shapes of the articular processes, and the orientations of the articular processes (Fig. 7A-D). The thoracic series appears to be continuous from $\mathrm{T} 1$ to $\mathrm{T} 10$. All ten of these vertebrae have two costal fovea, although the two surfaces are very close together in T10. The body of T11 appears to be missing, but a pair of transverse processes with bean-shaped articular surfaces are present. In Dorudon atrox, the most cranial thoracic vertebra with a single costal fovea has similar transverse processes. These may be from T11 or T12. The most caudal thoracic vertebra present (T13? or higher, Fig. 7D) has long transverse processes with a single articular surface for a rib on each side. The height of the body of this vertebra is about the same as the width of the body, unlike in more anterior thoracics, but similar to the lumbar vertebrae.

Lumbar vertebrae - Three poorly preserved lumbar vertebrae are present. The bodies are approximately as long as they are tall and wide. Transverse processes 

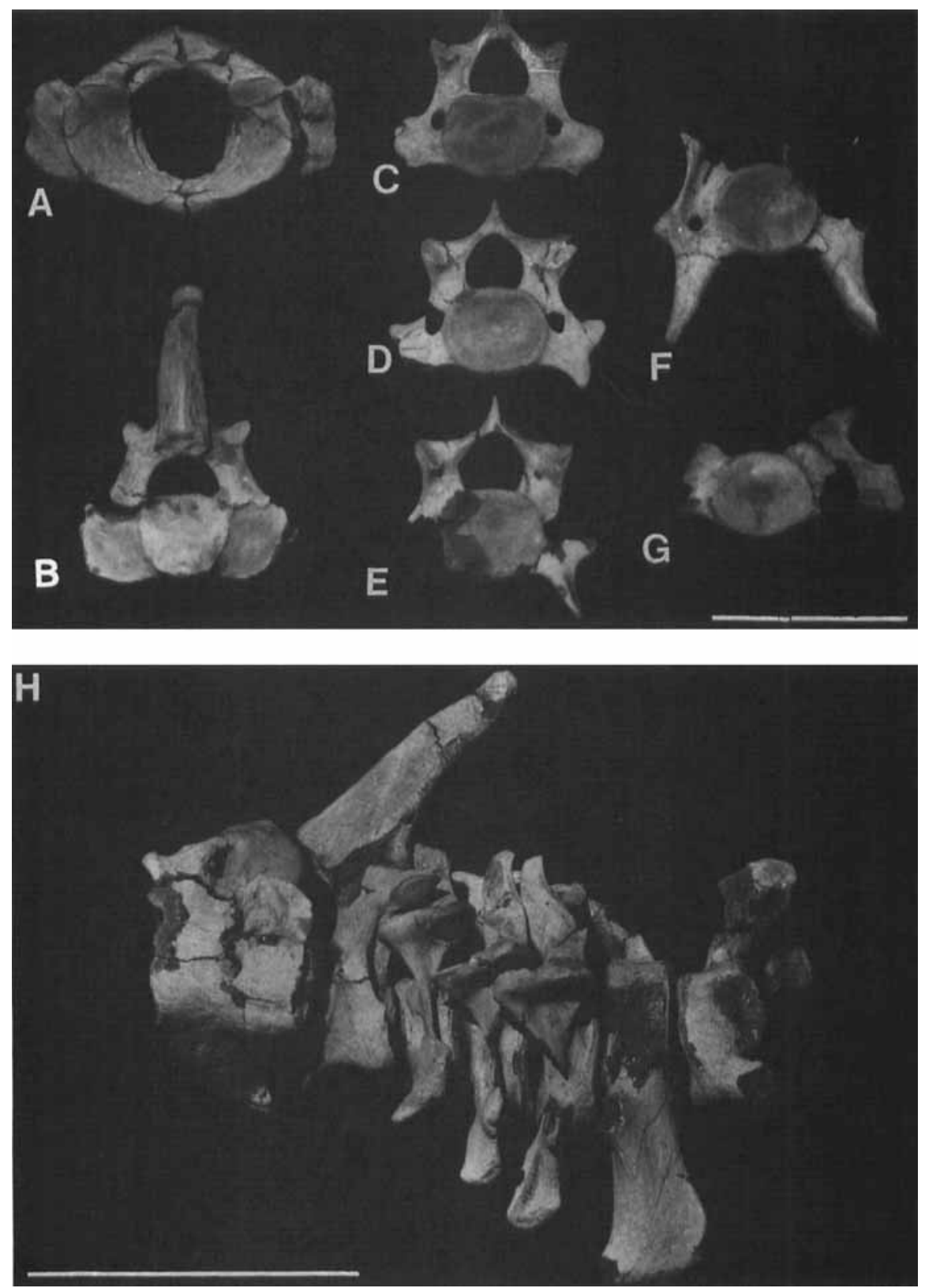

Figure 6. Cervical vertebrae of holotype of Chrysocetus healyorum, SCSM 87.195 in $A-G$, cranial views and $H$, lateral view. $A$, atlas, $C 1$. B, axis, C2. Note large neural spine of C2. C, C3. D, C4, E, C5. Note overall similarity of C3 to C5. F, C6. Note large ventrally projecting parapophyses of $\mathrm{C} 6 . \mathrm{G}, \mathrm{C} 7 . \mathrm{H}, \mathrm{C} 1-\mathrm{C} 7$. Scale bar equals 10 $\mathrm{cm}$. 
Table 2. Measurements of vertebral bodies of Chrysocetus bealyorum. All measurements in $\mathrm{mm}$ and accurate to $\pm 1 \mathrm{~mm}$.

\begin{tabular}{lllllll}
\hline \hline Vertebra & $\begin{array}{c}\text { Ventral } \\
\text { length }\end{array}$ & $\begin{array}{c}\text { Dorsal } \\
\text { length }\end{array}$ & $\begin{array}{c}\text { Anterior } \\
\text { width }\end{array}$ & $\begin{array}{c}\text { Posterior } \\
\text { width }\end{array}$ & $\begin{array}{c}\text { Anterior } \\
\text { height }\end{array}$ & $\begin{array}{c}\text { Posterior } \\
\text { height }\end{array}$ \\
\hline C1 & 31.9 & 29.0 & 110 & 99.6 & 19.2 & 16.1 \\
C2 & 35.2 & - & 102.5 & 53.5 & 28.3 & 43.4 \\
C3 & 22.0 & - & 53.8 & 58.1 & 42.7 & 43.7 \\
C4 & - & - & 55.5 & 56.0 & 45.7 & - \\
C5 & 21.4 & - & - & 54.0 & 46.8 & 48.6 \\
C6 & 22.8 & 22.3 & 52.6 & - & 48.0 & 45.9 \\
C7 & - & 24.9 & 54.7 & 71.9 & 46.2 & $-1.7^{\mathrm{b}}$ \\
T1 & 34.2 & $28.5^{\mathrm{b}}$ & 66.4 & $67.5^{\mathrm{b}}$ & 41.1 & $40.7^{\mathrm{b}}$ \\
T2 & 35.3 & 35.2 & 60.7 & 67.9 & 41.4 & 40.1 \\
T3 & 40.3 & 42.1 & 59.9 & 66.0 & 41.8 & 43.8 \\
T4 & $40.3^{\mathrm{b}}$ & $42.0^{\mathrm{b}}$ & 59.0 & 59.3 & 42.2 & $41.4^{\mathrm{b}}$ \\
T5 & $42.6^{\mathrm{a}}$ & $42.6^{\mathrm{a}}$ & 59.0 & 63.2 & $42.3^{\mathrm{a}}$ & 41.2 \\
T6 & 44.4 & 43.9 & 57.0 & 62.4 & 44.0 & 43.1 \\
T7 & 47.7 & 47.9 & - & - & 42.9 & 43.9 \\
T8 & 49.7 & 49.7 & - & - & 43.9 & - \\
T9 & $44.3^{\mathrm{c}}$ & - & $71.9^{\mathrm{c}}$ & - & $45.5^{\mathrm{c}}$ & - \\
T10 & $50.5^{\mathrm{b}}$ & $49.9^{\mathrm{b}}$ & 73.7 & $72.8^{\mathrm{b}}$ & 50.8 & $48.7^{\mathrm{b}}$ \\
T13? & $55.9^{\mathrm{b}}$ & 56.8 & 68.9 & $71.2^{\mathrm{b}}$ & 59.4 & $61.7^{\mathrm{b}}$ \\
LA & $53.9^{\mathrm{c}}$ & $61.0^{\mathrm{b}}$ & - & 73.4 & 63.3 & 62.9 \\
LB & $55.5^{\mathrm{c}}$ & - & $74.3^{\mathrm{c}}$ & - & $63.4^{\mathrm{c}}$ & $64.6^{\mathrm{c}}$ \\
LC & $55.5^{\mathrm{c}}$ & - & - & - & - & - \\
\hline
\end{tabular}

${ }^{2}$ Missing anterior epiphysis.

${ }^{b}$ Missing posterior epiphysis.

${ }^{c}$ Missing both epiphyses.

arise from the ventral portion of the lateral side of the body, and these angle slightly ventrally. Pedicles of the neural arches are almost as long as each vertebral body and are closer to the cranial end than the caudal end. It is unclear how many lumbar vertebrae were present in Chrysocetus bealyorum. No sacral or caudal vertebrae were recovered with the type specimen.

Sternum and ribs--Three sternal elements were recovered: the manubrium and two mesosternal elements (Fig. 8A). The xiphisternum is presently unknown. The sternal elements are dorsoventrally thick, and their articular surfaces are covered with rough, spongy bone. The manubrium is craniocaudally elongate, and the cranial end flares laterally. There is a slight dorsal bend in the body of the manubrium about two-thirds of the way from the cranial end to the caudal end. The caudal end is U-shaped in dorsal and ventral views. One of the mesosternal elements is similar in shape to the manubrium, but the presumed cranial end is flat and the body lacks a dorsal bend. The other mesosternal element is pentagonal, with the articular surface wrapping almost all the way around the body. Both mesosternal elements have slightly concave dorsal and ventral surfaces.

Ribs of $C$. bealyorum are similar to those of other dorudontines (Fig. 8B). The anterior ribs have both heads and tubercles. More posterior ribs lack 

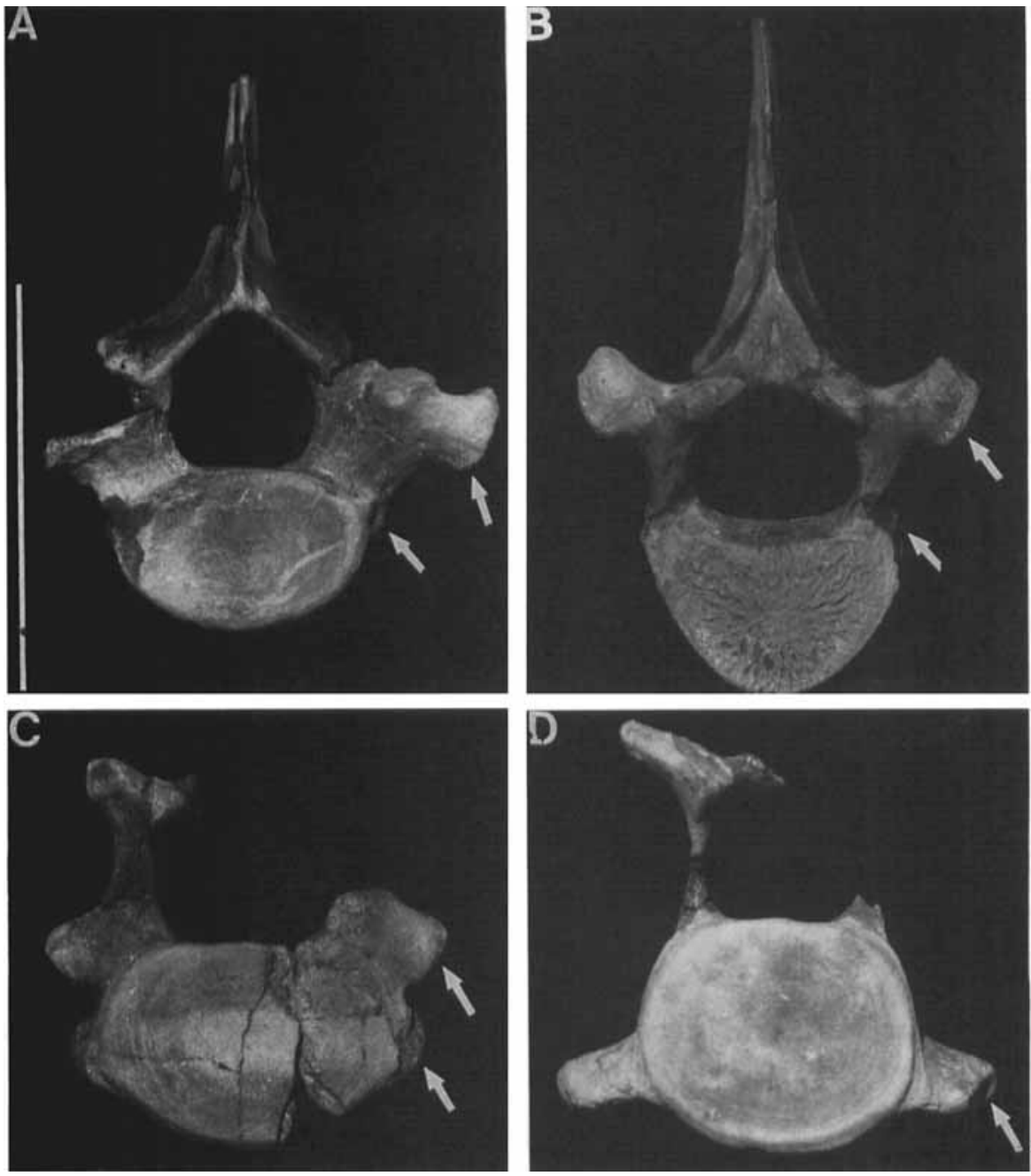

Figure 7. Thoracic vertebrae of holotype of Chrysocetus bealyorum, SCSM 87.195. A, T1. B, T5. C, T10. Note close proximity of costal fovea on sides. D, T13? Note presence of single costal fovea placed on long transverse process. Arrows indicate positions of costal fovea on one side of each vertebra. Scale bar equals $10 \mathrm{~cm}$.

tubercles. Based on the distribution of costal fovea on the thoracic vertebrae, this transition takes place somewhere around rib ten. The most anterior ribs are short and stout. The longest ribs are around rib five or six; they are somewhat pachyostotic, but not osteosclerotic. The ribs lack a medullary cavity and the pachyostotic ribs are filled with spongy bone.

Scapula-The scapula of Chrysocetus bealyorum is similar to those of other basilosaurids, and in many ways to the scapulae of modern cetaceans (Fig. 9A). It is broadly fan-shaped with well-developed supraspinous, infraspinous, and teres fossae on the lateral face. The infraspinous fossa is very large in compar- 

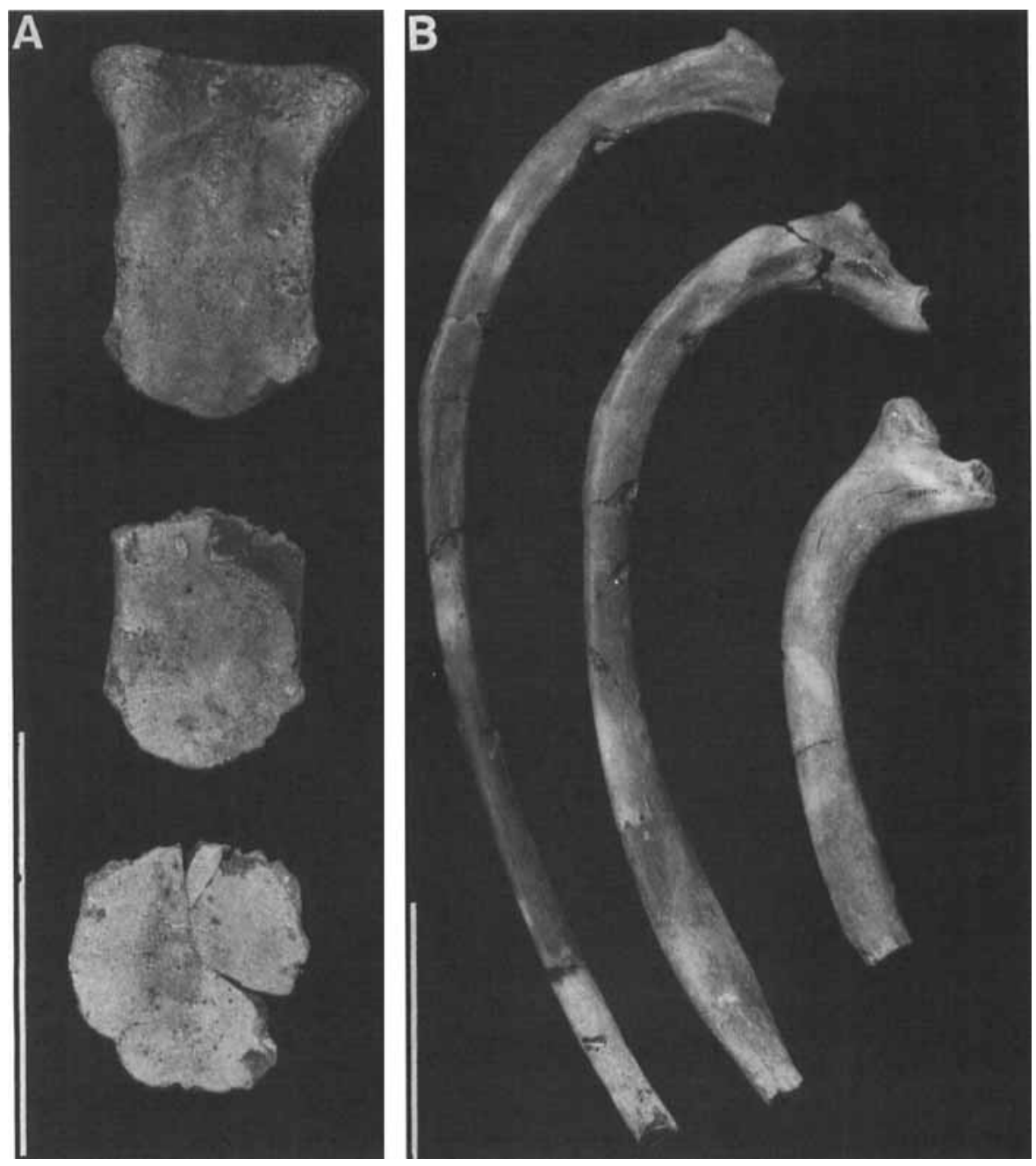

Figure 8. A, sternum and B, ribs of holotype of Chrysocetus bealyorum, SCSM 87.195. Top element in A is manubrium, while others are mesosternal elements. Rib farthest to right is first rib, middle rib is probably around rib 4, while rib farthest to left is probably around rib 6 . Scale bars both equal $10 \mathrm{~cm}$.

ison with the supraspinous fossa. A long and laterally flat acromion process projects laterally from the spine, and then immediately angles cranially. The acromion process is laterally flat. A shorter and more robust coracoid process projects cranially from the cranial border of the scapular neck, where it meets the glenoid cavity. Both the acromion and coracoid processes are fully fused to the scapular neck. The glenoid cavity faces ventrally, and is pyriform, with the small end pointing cranially. The glenoid cavity is shallowly convex, with a thick, gently rounded margin.

Humerus - The humerus is similar to those of other dorudontines, notably 


Zygorbiza kocbii (Fig. 9B). Both Zygorbiza and Cbrysocetus have humeri that are more gracile in form than those of Dorudon. The proximal epiphysis of the humerus, which bears the head and greater and lesser tubercles, is not fused to the shaft. The head is roughly hemispherical in shape and faces slightly posteriorly. Greater and lesser tubercles project about as far proximally as the edge of the humeral head. The shaft of the humerus bears a large deltopectoral crest on the cranial border, which projects farthest from the shaft on its distal end. The distal end of the humerus bears a single articular trochlea for both the ulna and radius.

Ulna-The ulna has a large olecranon process proximal to the trochlear notch (Fig. 9B). The anterior edge of the trochlear notch articulates with the more cranially positioned radius. The shaft is laterally flattened, and flares craniocaudally at its distal end. Both epiphysis from the olecranon process and the distal epiphysis are unfused and missing.

Radius - The head of the radius is gently convex with the shape of a flattened oval (Fig. 9B). The flat side of the articular circumference of the radius is on its caudal face and articulates with the ulna. The shaft of the radius is laterally flattened. There is a slight bend in the shaft about one third of the way from the head to the distal end, where there is a tuberosity on the cranial border. The distal end is slightly flared, and the distal epiphysis is missing.

Phalanges-No elements of the carpus or metacarpus were recovered with the type specimen. Two phalanges were recovered, one complete, and the other missing its distal end (Fig. 9C). They are similar to the proximal phalanges described from Dorudon atrox (Uhen 1998), although it is not clear which phalanges they represent. The proximal ends of both phalanges are slightly convex and in the shape of flattened ovals. The shafts taper from proximal to distal and become flattened in the plane of the palm. The phalanges are relatively long and narrow. The one complete phalanx shows that the shaft flares distally to form an oval-shaped distal articular surface.

Innominate-Most of the left pelvis (Fig. 10) and fragments of the right pelvis have been recovered. Despite the young age of the individual (discussed below), no sutures between the three bones of the pelvis (ilium, ischium, and pubis) are visible. The pelvis shows a greatly elongated pubis and very reduced ilium. Much of the ischium is broken.

The ilium of Cbrysocetus bealyorum is reduced to a small process and part of the acetabulum (Fig. 10A-C). The process of the ilium is similar to but much narrower than the process of the ilium in Basilosaurus. Both Cbrysocetus and Basilosaurus differ from the protocetid archaeocete Rodhocetus kasrani and from

$\leftarrow$

Figure 9. Left forelimb elements, A, scapula; B, humerus, radius and ulna; C, phalanges of holotype of Chrysocetus bealyorum, SCSM 87.195. Note that head of humerus not fused to shaft and radius and ulna both missing distal epiphyses. Scale bar for $\mathrm{A}$ and $\mathrm{B}$ equals $10 \mathrm{~cm}$. Scale bar for $\mathrm{C}$ equals $5 \mathrm{~cm}$. 

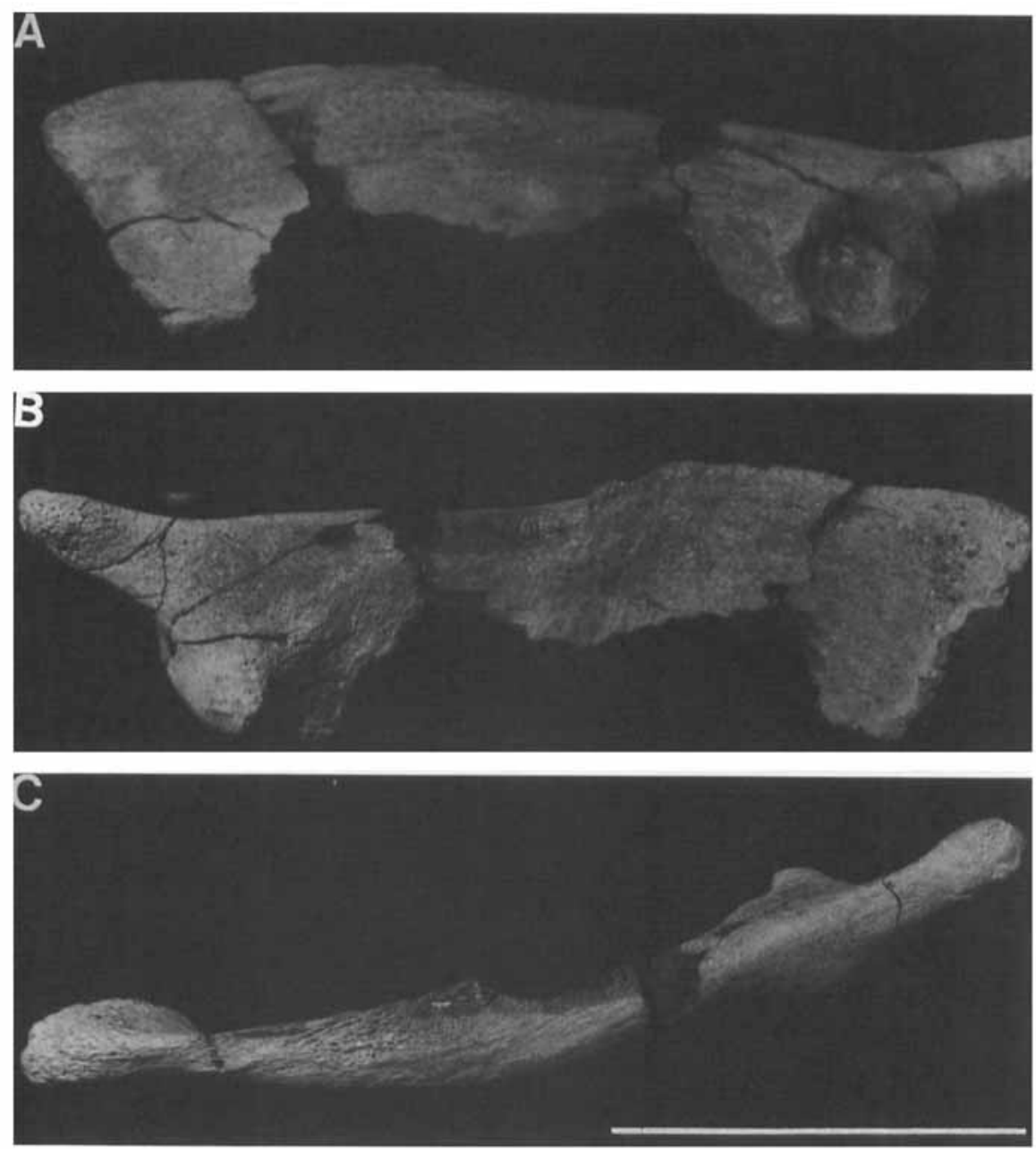

Anterior view

terrestrial mesonychids in having a greatly reduced ilium (Zhou et al. 1992, Gingerich et al. 1994).

This ischium of Cbrysocetus bealyorum is mostly broken. It formed part of the acetabulum and the posteromedial margin of the obturator foramen (Fig. $10 \mathrm{~A}, \mathrm{C})$. An obturator foramen is certainly present, since the anterolateral margin of the foramen forms an unbroken edge of the pubis proximal to the acetabulum. The dorsal side of the ischium presents a robust protuberance along its posterolateral margin. This protuberance does not have a clear homologue in other cetaceans or terrestrial mammals. It was probably a site for attachment of muscles or ligaments that held the pelvis in place.

The acetabulum itself seems to be formed from contributions from the ilium, ischium, and pubis. Here it is generally round, with a well-developed rim on the iliac and ischial margins (Fig. 10A). The rim is lower on the pubic margin, and there is also a small notch in this margin. The acetabulum is deep and the surface is well formed and smooth. The smoothness of the surface indicates that there was a functional synovial hip joint for articulation with the head of the femur.

The body of the pelvis is formed from the greatly elongated pubis. The pubis extends from the acetabulum to the pubic symphysis (Fig. 10A-C). Near the acetabulum the pubis forms the anteromedial margin of the obturator foramen. The anterolateral margin of the pubis is thickened on the ventral side and forms a sharp ridge on the dorsal side. These two structures delimit a space for muscle attachment. The only muscles that attach to this margin of the pubis in modern terrestrial mammals are the pectineus and rectus abdominus muscles. It is unlikely that the pectineus was retained in the greatly reduced hindlimb of basilosaurid archaeocetes, because its action is to assist in adduction of the femur and extension of the hip joint (Evans 1993). Other larger muscles of the hip were probably retained to move the femur through the limited range of motion hypothesized for basilosaurid hind limbs (Gingerich et al. 1990). The rectus abdominus, however, would have performed the vital function of keeping the pelvic girdle in place in the body wall.

The body of the pubis broadens towards the pubic symphysis. The symphyseal surface is preserved in both the left and right pelves. The surface is covered with rough, spongy bone indicative of a cartilaginous articulation of the right and left pelves. The position of the pelves in the body wall can be determined by aligning the articulation of the pelves parallel to the midline of the body. When articulated in this fashion, the pelves curve outward from the pubic symphysis, forming a chevron-shaped structure pointing anteriorly at the pubic symphysis. The dorsal surfaces of the articulated pelves are con-

$\leftarrow$

Figure 10. Left innominate of holotype of Chrysocetus bealyorum, SCSM 87.195 in $A$, ventrolateral, B, dorsomedial, and C, anterior views. Note well-formed acetabulum, antero-lateral margin of obturator foramen, and greatly elongated pubis. Scale bar equals $5 \mathrm{~cm}$. 
cave (Fig. 10B) and are presumably parallel to the outer surface of the fusiform body wall. This shape and the position of the pelvis in the body are similar to the state in Basilosaurus (Gingerich et al. 1990). There is no bony contact between the innominata and sacral vertebrae.

\section{Discussion}

The supraoccipital/parietal suture of the skull of the type specimen of Chrysocetus bealyorum is partially fused, while the parietal/squamosal and the parietal/frontal sutures are open. The epiphyses of the cervical vertebrae are firmly attached to the vertebral bodies, but they are not completely fused to the vertebral bodies. The epiphyses of the thoracic vertebrae are very loosely attached to the vertebral bodies or not attached at all. The humeral head is not fused to the shaft, and the proximal and distal epiphyses of the radius and ulna are missing and were not fused to their respective shafts.

The incisors and canines of Cbrysocetus bealyorum all have long, fully closed roots. The upper first incisors are in place in the premaxillae, and breakage of the premaxillae shows that the roots are fully formed and show no signs of resorption. The premolars of $C$. bealyorum have tall crowns with numerous accessory denticles. They also have long, fully closed roots (Fig. 3 A-B). In addition, these roots angle toward each other, rather than away from each other as seen in deciduous teeth of other dorudontines (Uhen 1996).

The features of the teeth of Chrysocetus bealyorum are normally found on adult dorudontine teeth, yet, based on the ontogenetic stage of skeletal fusion in other dorudontines, the individual in question is clearly a subadult. In other dorudontines such as Dorudon atrox and Zygorbiza kochii, this stage of cranial, vertebral, and long-bone epiphyseal fusion corresponds to an early stage in eruption of the adult dentition. Figure 11 shows how the epiphyseal fusion stage of the type specimen of $C$. bealyorum compares to a juvenile specimen of $D$. atrox just beginning to erupt its second molars (Uhen 1996), and a specimen of $Z$. kochii almost completing its dental eruption (Kellogg 1936) and how all three dorudontines compare to juvenile domestic goats (Capra capra) and finless porpoises (Neophocaena phocaenoides) of different ages. Both of these charts show that, based on the epiphyseal fusion stage, the type specimen of $C$. healyorum is ontogenetically older than the specimen of $D$. atrox just beginning to erupt its second molars (UM 93220) and younger than the specimen of $Z$. kochii almost completing its dental eruption (USNM 16639).

This indicates that the dental development of $C$. bealyorum did not follow the same trajectory as other archaeocetes. It either replaced the deciduous dentition very early in development relative to skeletal maturation, or it never had deciduous teeth and instead erupted teeth of adult morphology early in development relative to skeletal maturation. All other archaeocetes retain the pattern of replacement of the deciduous dentition with an adult dentition (diphyodonty), which is primitive for therian mammals (Kellogg 1936). In contrast, modern suborders of Cetacea (Odontoceti and Mysticeti) both erupt only a single set of teeth (monophyodonty). No known living or fossil odon- 


\title{
Skeletal maturity in Capra months
}

\author{
$\begin{array}{lll}D . \text { atrox } & \text { C. healyorum } & Z \text {. kochii }\end{array}$
}

\begin{tabular}{|c|c|c|c|c|c|c|c|c|c|c|c|}
\hline Neonat. & $12 \mathrm{mo}$. & $24 \mathrm{mo}$. & 93220 & $36 \mathrm{mo}$. & 87.195 & $48 \mathrm{mo}$. & 16639 & $60 \mathrm{mo}$. & $72 \mathrm{mo}$. & Age (Capra-months) & \\
\hline & $m$ & $m$ & & $-m$ & & $m$ & & $-m$ & $m$ & Premax.-maxilla & \\
\hline & & & DDOD & & DODO & DODID & $-m$ & 826 & & Frontal-parietal & \\
\hline & $m$ & $m$ & $\cdot m$ & $-m$ & $-m$ & $m$ & & $-m$ & $m$ & Basisph.-basiocc. & \\
\hline & $m$ & $m$ & 28 & $m$ & & $m$ & & $-m$ & $m$ & Squamosal-parietal & \\
\hline & & & & & & & & & 202 & Parietal-occipital & $\underline{E}$ \\
\hline & $m$ & $-m$ & 9 & $m$ & $m$ & $m$ & & $-m$ & $m$ & Supraocc,-exoccip. & 嵌 \\
\hline & $\cdot m$ & $-m$ & 1282 & $m$ & $-m$ & $m$ & & $-m$ & $m$ & Exocc.-basioccip. & 崩 \\
\hline & DOPOC: & & & & $m$ & & & & & M2 eruption & \\
\hline & & & 2000 & 20 & $m$ & & 8 & & & M3 eruption & \\
\hline & & & & & $m$ & DIIIIS & . & & & Last perm. tooth & \\
\hline & $m$ & $-m$ & & $\cdot m \cdot$ & $8 x$ & $m$ & & $-m$ & $m$ & Atlas dorsal arch & \\
\hline & $m$ & $-m$ & & $m$ & 8 & $m$ & & $-m$ & $m$ & Atlas ventral arch & \\
\hline & $m$ & $-m$ & & $-m$ & & $m$ & & $m$ & $m \cdot$ & Axis dens & \\
\hline & $-m$ & $m$ & & $-m$ & & $m$ & & $m$. & $m$ & Axis cent. epiph. & \\
\hline & $-m$ & $-m$ & & $-m$ & & $m$ & & $m \cdot$ & $m$ & Cerv. trans. proc. & \\
\hline & $m$ & $m$ & & $m$ & & $m$ & & $-m \cdot$ & $m \cdot$ & Cerv. neur, arch & $\Phi$ \\
\hline & $-m$ & $m$ & 18808 & $-m$ & 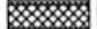 & $m$ & 1808 & $-m$ & $m$ & Cerv. cent. epiph. & ๕ \\
\hline & $m$ & $-m$ & & $-m$ & & $m$ & & $m$ & $\cdot m \cdot$ & Thor. trans. proc. & ङ \\
\hline & $-m$ & $-m$ & 828 & $m$ & & $-m \cdot$ & & $-m \cdot$ & $m$ & Thor, neur. arch & 兵 \\
\hline & $-m$ & $m$ & & $-m$ & DIIIII & $-m \cdot$ & & $-m \cdot$ & $m$ & Thor. cent. epiph. & \\
\hline & $m$ & $-m$ & & $m$ & & $-m \cdot$ & $-m$ & $-m \cdot$ & $-m$ & Lumb. trans. proc. & \\
\hline & $-m$ & $-m$ & & $m$ & & $-m \cdot$ & $-m$ & $+m \cdot$ & $-m$ & Lumb. neur. arch & \\
\hline & $-m$ & $-m$ & & $m$ & & $m$ & $m \cdot$ & $m \cdot$ & $m$ & Lumb. cent. epiph. & \\
\hline & $m$ & $-m$ & & $m$ & DDPA & $m$ & & $\cdot m$ & $m$. & Rib heads & 员 \\
\hline & $m$ & $m$ & s. & $m$ & & $m$ & 28 & $-m$ & $m$ & Rib tubercula & 起 \\
\hline & DIIIII & & $\cdot m \cdot$ & & & & $\rightarrow m$ & & & Scap. coracoid & \\
\hline & $-m$ & $m$ & $-m$ & $-m$ & & $m$ & $m$ & $-m$ & $m$ & Scap. acrom. tip & \\
\hline & $-m$ & $m$ & $-m$ & $-m$ & & $-m$ & $m$ & $-m \cdot$ & $-m$ & Scap. vert. border & \\
\hline & $-m$ & $m$ & $-m$ & $m$ & $m$ & $-m$ & $m$ & $m$ & $m$ & Scap. post. angle & \\
\hline & & & $-m$ & & & QDIDI & $-m$ & 8 & & Humerus proximal & \\
\hline & & DPCD & $-m$ & \% & & & $-m \cdot$ & & & Humerus entepicond. & 욜 \\
\hline & & & $-m$ & & & & $-m$ & & & Humerus distal & EE \\
\hline & & & $-m$ & & & & $-m$ & & & Radius proximal & 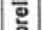 \\
\hline & & & $-m$ & & & ZIII & $-m+$ & x. & & Radius distal & 문 \\
\hline & & & $-m \cdot$ & & & & $m \cdot$ & & & Ulna proximal & \\
\hline & & & $-m \cdot$ & & & & $m$ & & 18 & Ulna distal & \\
\hline & & & $-m \cdot$ & \% & $m \cdot$ & & $m \cdot$ & & & Metacarpal epiph. & \\
\hline & QDIIIS & $8 \% 8$ & $m$ & $1 \%$ & & & $m$ & & & Carp. phal. epiph. & \\
\hline & 27112 & & $m$ & & & & $m$ & & & Innom. il.-is.-pub. & 흘 \\
\hline & & & $-m \cdot$ & & $m$ & & $m$ & 18 & & Innom. il. crest & 돈 \\
\hline
\end{tabular}

\section{Skeletal maturity in Neophocaena years}

D. atrox

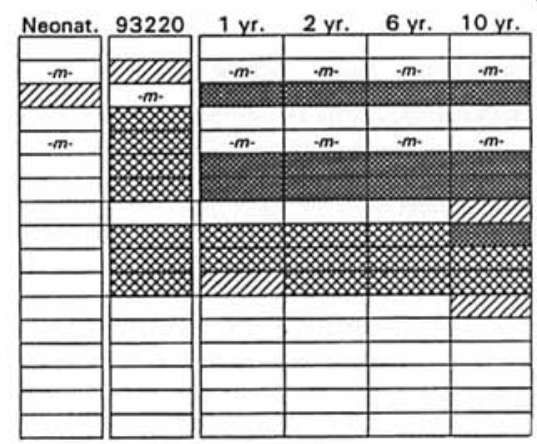

C. healyorum Z. kochii

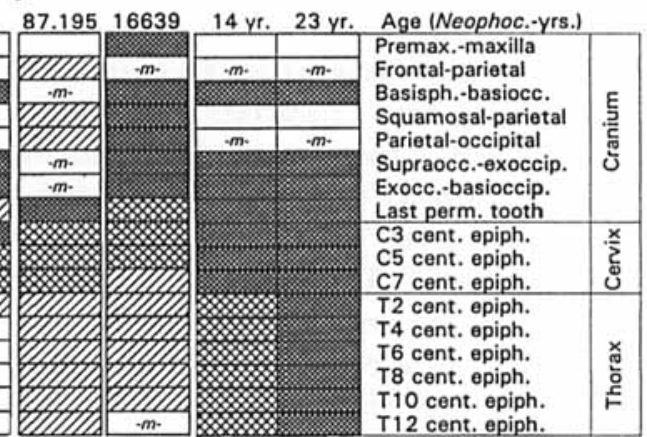

Key: $\square$ no dev. IIIIA initial partial complete $\cdot m \cdot$ missing datum

Figure 11. Epiphyseal fusion stage of holotype of Chrysocetus bealyorum (SCSM 87.195), juvenile Dorudon atrox (UM 93220), and juvenile Zygorbiza kocbii (USNM 16639), compared to sample of known-age specimens of Capra capra and Neophocaena phocaenoides. Comparative framework developed by Gingerich and Smith (unpublished), Neophocaena phocaenoides data from Yoshida et al. (1994), and Capra capra data from Noddle (1974) and Bullock and Rackham (1982). 
tocetes replace their teeth (Fordyce 1982), and mysticetes develop a single set of teeth that is later resorbed in utero (Karlsen 1962).

\section{Phylogenetic Relationships}

A phylogenetic analysis was performed on Chrysocetus bealyorum, other basilosaurids, selected non-basilosaurid archaeocetes, and hypothetical ancestral mysticetes and odontocetes. The analysis was performed on the character matrix listed in Appendix 1. The analysis was performed using stratocladistics, a phylogenetic analysis method that includes morphologic character data like a conventional cladistic analysis, as well as information about the relative stratigraphic relationships of fossils.

Stratocladistics uses both morphologic and stratigraphic data in a parsimony-based cladistic analysis to determine the phylogenetic relationships of taxa under study (Fisher 1992, 1994). If morphologic data suggests that taxa $B$ and $C$ diverged from a common ancestor later than either does from a common ancestor with taxon $A$, then $A$ should be found earlier in the fossil record than $B$ and $C$. If $A$ is not found earlier than $B$ and $C$, one is required to construct an ad boc hypothesis of non-preservation to explain the absence of $A$. When evaluating alternative hypotheses, stratocladistic analysis will "penalize" this hypothesis for requiring the use of an ad hoc hypotheses of nonpreservation. This method treats ad boc hypotheses that explain away missing fossils in the same way as ad boc hypotheses of homoplasy. Stratocladistics allows one to construct phylogenies that include ancestor-descendant relationships like the one shown here.

Stratocladistic analyses must be performed in two steps, because no phylogenetic analysis program includes both optimal tree-finding algorithms and the stratigraphic character type. First, a preliminary phylogenetic analysis was performed on 20 taxa using the morphologic characters (1-68 in Appendices 1 and 2) using PAUP 4.0b3 (Swofford 2000). Three of the taxa (Dissacus, Pacbyaena, and Sinonyx) were considered outgroup taxa, while the rest (17) were ingroup taxa. Characters were equally weighted, and multistate characters were ordered. Characters were chosen that vary in state among taxa in the analysis. A branch-and-bound search was performed, which guarantees to find the optimal tree. Thirty morphologically most parsimonious trees of length 164 were found. The matrix and these trees were then taken into MacClade 3.07 (Maddison and Maddison 1992), where the stratigraphic character (69) was added. As a result, the treelengths of the 30 trees ranged from 180 to 184 , with three trees of length 180 . These three trees were further explored by assigning taxa to ancestral positions using the "make ancestor tool" in MacClade and by swapping branches by hand. A single topology was found to be overall most parsimonious. In this topology (Fig. 12) some taxa may be placed in ancestral positions that do not affect the treelength, but only those taxa that shorten the treelength when they are placed in ancestral positions are shown in those ancestral positions in Figure 12. The resulting phylogenetic tree has an overall treelength of 176 steps. 


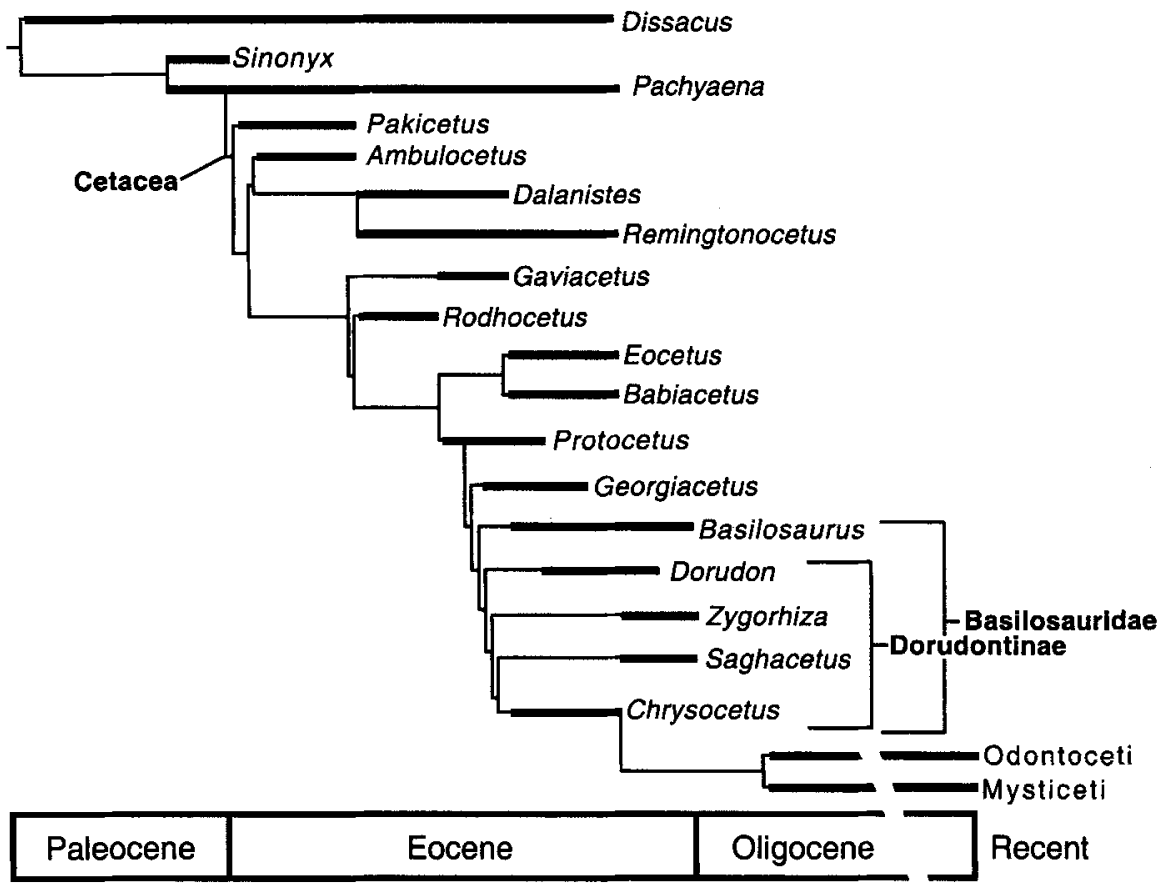

Figure 12. Phylogenetic tree depicting relationships among and stratigraphic ranges of selected archaeocete cetaceans, mesonychid condylarths, and modern cetaceans. Phylogenetic tree constructed using stratocladistics, method of phylogenetic analysis that utilizes both morphological and stratigraphic data to determine overall most parsimonious hypothesis of relationships (Fisher 1992, 1994). Thick horizontal bars represent stratigraphic ranges (including some additional length due to lack of age precision), while thin horizontal bars and vertical bars represent phylogenetic relationships. Stratigraphic ranges based on Gingerich et al. (1997) and McKenna and Bell (1997). Dissacus, Sinonyx, and Pachyaena are outgroups to order Cetacea, which in this hypothesis includes common ancestor of Pakicetus and clade (Ambulocetus + Remingtonocetidae) and all descendants. Basilosauridae includes Basilosaurus and Dorudontinae. Dorudontinae includes common ancestor of Zygorbiza and Dorudon and all descendants other than Mysticeti and Odontoceti. Chrysocetus has accelerated eruption of adult dentition, interpreted as stage in evolution of monophyodonty. Chrysocetus is plesiomorphic relative to Odontoceti and Mysticeti in all other characters in matrix. This, plus its stratigraphic position earlier than any known mysticete or odontocete, suggests it is ancestral to modern suborders of Cetacea.

Many characters indicate that the Odontoceti and Mysticeti form a monophyletic group that is derived from Dorudontinae. These characters include loss of the sacrum, rotation of the pelvis, reduction of the pelvic girdle and hind limb, presence of multiple accessory denticles on the cheek teeth (later lost in odontocetes and mysticetes), radius and ulna articulating with the humerus in a common trochlea, and lack of saddle-shaped articular surfaces on the carpals.

Given this evidence, one would expect that the common ancestor of Odontoceti + Mysticeti would have most of the characters of dorudontines with a 
few of those that unite the modern suborders. Chrysocetus healyorum appears to be just that, a representative dorudontine with a single, derived character of Odontoceti + Mysticeti: the development of accelerated eruption of adult teeth as a possible step towards monophyodonty. Since Chrysocetus is also not highly autapomorphic it represents a good candidate for the ancestry of modern cetaceans. As more fossil cetaceans are discovered, they may fit into the phylogeny as more recent common ancestors of Odontoceti + Mysticeti than Chrysocetus, without being either odontocetes or mysticetes.

The recognition of accelerated adult dental eruption in Chrysocetus bealyorum as the homologue of the permanent dentition of other archaeocetes has a number of implications for interpretation of the dentition of odontocetes and mysticetes. It has been suggested that the polydont dentition of odontocetes originally developed by eruption of the permanent dentition between teeth of the deciduous dentition in the canine and premolar fields (Fordyce 1982). If the deciduous dentition of Cbrysocetus was never erupted and monophyodonty is a shared derived character among Chrysocetus, Odontoceti, and Mysticeti, then polydonty must have arisen from some other mechanism. Recent discoveries of very primitive mysticetes (Barnes and Sanders 1996), that have teeth that are characteristically basilosaurid indicate a different origin of polydonty. These primitive mysticetes have three upper molars and four lower molars, along with a number of characters that ally them with basilosaurids. Since basilosaurids have only two upper molars and three lower molars, the primitive mysticetes must have added the extra molars by terminal addition. They could not have increased the number of teeth by retaining a deciduous premolar, since the molars are distinctly different from the deciduous premolars in both basilosaurid archaeocetes and these early mysticetes, and the additional tooth has the molar morphology.

\section{Summary and Conclusions}

The pelvis of Cbrysocetus bealyorum shares many derived characters with the pelves of Basilosaurus, further demonstrating the close relationship of Basilosaurinae and Dorudontinae. The more primitive Ambulocetidae (Gingerich $e t$ al. 1994; Thewissen et al. 1994, 1996), Protocetidae (Hulbert et al. 1998), and Remingtonocetidae (Gingerich et al. 1995) show many more features of the pelves in common with the terrestrial mesonychid relatives of cetaceans than with the more derived basilosaurids. Many of these plesiomorphic characters indicate that protocetids, ambulocetids, and remingtonocetids could use their hind limbs to support their bodies on land (Gingerich et al. 1994, Thewissen et al. 1996). Pelves of Chrysocetus also demonstrate that dorudontines were at a similar stage of hindlimb reduction as Basilosaurus and, thus, that the ancestors of modern whales and dolphins had already attained a fully aquatic mode of life. Cbrysocetus not only shares a number of derived characters with other dorudontines, but it also may have accelerated adult dental eruption or possibly monophyodonty in common with modern cetaceans. If Cbrysocetus is interpreted as an ancestor of Odontoceti + Mysticeti, the monophyodont 
dentition of modern cetaceans may be interpreted to be homologous with the adult dentition of archaeocetes.

\section{ACKNOWLEDGMENTS}

We would like to thank Craig and Alice Healy who originally discovered the type specimen, performed most of the preparation of the specimen, and donated it to the South Carolina State Museum. James L. Knight brought the specimen to our attention and loaned it to us for study. We also thank R. Ewan Fordyce and an anonymous reviewer for their helpful comments on an earlier version of this work. This research was conducted with the support of National Science Foundation grant \#EAR-9714923.

\section{Literature Cited}

Barnes, L. G., And E. Mitchell. 1978. Cetacea. Pages 582-602 in V. J. Maglio and H. B. S. Cooke, eds. The evolution of African mammals. Harvard University Press, Cambridge, MA.

Barnes, L. G., AND A. E. Sanders. 1996. The transition from Archaeoceti to Mysticeti: Late Oligocene toothed mysticetes from South Carolina, U.S.A. Journal of Vertebrate Paleontology 16:21A.

Barnes, L. G., D. P. Domning AND C. E. Ray. 1985. Status of studies on fossil marine mammals. Marine Mammal Science 1:15-53.

Baum, G. R., J. S. Collins, R. M. Jones, B. A. Madlinger and R. J. Powell. 1980. Correlation of the Eocene strata of the Carolinas. South Carolina Geology 24:1927.

Berggren, W. A., D. V. Kent, C. C. Swisher and M.-P. Aubry. 1995. A revised Cenozoic geochronology and chronostratigraphy. Pages 129-212 in W. A. Berggren, D. V. Kent, M.-P. Aubry and J. Hardenbol, eds. Geochronology, time scales and global stratigraphic correlation, SEPM Special Publication 54. SEPM, Tulsa, OK.

Brisson, A. D. 1762. Pages 294 Regnum Animale in Classes IX distributum sive synopsis methodica. Edito altero auctior. Theodorum Haak, Leiden, Netherlands.

Bullock, D., AND J. RackHam. 1982. Epiphyseal fusion and tooth eruption of feral goats from Moffatdale, Dumfries and Galloway, Scotland. Pages 73-80 in B. Wilson, C. Grigson and S. Payne, eds. Aging and sexing animal bones from archaeological sites, British Series, 109. BAR, Oxford.

COPE, E. D. 1867(1868). An addition to the vertebrate fauna of the Miocene period, with a synopsis of the extinct Cetacea of the United States. Proceedings of the Academy of Natural Sciences of Philadelphia 19:138-156.

Evans, H. E. 1993. Miller's anatomy of the dog. W. B. Saunders Company, Philadelphia, PA.

Fisher, D. C. 1992. Stratigraphic parsimony. Pages 124-129 in W. P. Maddison and D. R. Maddison, eds. MacClade 3.0 manual. Sinauer Associates, Sunderland, MA.

Fisher, D. C. 1994. Stratocladistics: Morphological and temporal patterns and their relation to phylogenetic process. Pages 133-171 in L. Grande, and O. Rieppel, eds. Interpreting the hierarchy of nature. Academic Press, San Diego, CA.

FLOWER, W. H. 1883. On the arrangement of the orders and families of existing Mammalia. Proceedings of the Zoological Society of London 1883:178-186.

FORDYCE, R. E. 1982. Dental anomaly in a fossil squalodont dolphin from New Zealand, and the evolution of polydonty in whales. New Zealand Journal of Zoology 9:419-426.

Fordyce, R. E., AND L. G. Barnes. 1994. The evolutionary history of whales and dolphins. Annual Review of Earth and Planetary Sciences 22:419-455. 
Gidley, J. W. 1913. A recently mounted zeuglodon skeleton in the United States National Museum. Proceedings of the United States National Museum 44:649654 .

Gingerich, P. D., B. H. Smith and E. L. Simons. 1990. Hind limbs of Eocene Basilosaurus: Evidence of feet in whales. Science 229:154-157.

Gingericit, P. D., S. M. Raza, M. Arif, M. Anwar and X. Zhou. 1994. New whale from the Eocene of Pakistan and the origin of cetacean swimming. Nature 368: $844-847$.

Gingerich, P. D., M. Arif ANd W. C. CLYde. 1995. New archaeocetes (Mammalia, Cetacea) from the middle Eocene Domanda Formation of the Sulaiman Range, Punjab (Pakistan). Contributions from the Museum of Paleontology, University of Michigan 29:291-330.

Gingerich, P. D., M. Arif, M. A. Bhatti, M. Anwar and W. J. Sanders. 1997. Basilosaurus drazindai and Basiloterus bussaini, new Archaeoceti (Mammalia, Cetacea) from the middle Eocene Drazinda Formation, with a revised interpretation of ages of whale-bearing strata in the Kirthar Group of the Sulaiman Range, Punjab (Pakistan). Contributions from the Museum of Paleontology, University of Michigan 30:55-81.

Harris, W. B., V. A. Zullo and R. A. LAws. 1993. Sequence stratigraphy of the onshore Palaeogene, southeastern Atlantic Coastal Plain, USA. Sequence Stratigraphy and Facies Associations. The International Association of Sedimentologists Special Publication Number 18:537-561.

Hulbert, R. C., R. M. Petkewich, G. A. Bishop, D. Bukry and D. P. Aleshire. 1998. A new middle Eocene protocetid whale (Mammalia: Cetacea: Archaeoceti) and associated biota from Georgia. Journal of Paleontology 72:905-925.

KARLSEN, K. 1962. Development of tooth germs and adjacent structures in the whalebone whale (Balaenoptera physalus (L.)). Hvalrådets Skrifter: Scientific Results of Marine Biological Research 45:1-56.

KelLOGG, R. 1936. A review of the Archaeoceti. Carnegie Institute of Washington 482:1-366.

Köhler, R., AND R. E. Fordyce. 1997. An archaeocete whale (Cetacea: Archaeoceti) from the Eocene Waihao Greensand, New Zealand. Journal of Vertebrate Paleontology 17:574-583.

LiNNÉ, C. 1758. Systema Naturae. British Museum (Natural History), London.

LuCAS, F. A. 1900. The pelvic girdle of zeuglodon Basilosaurus cetoides (Owen), with notes on other portions of the skeleton. Proceedings of the United States National Museum 23:327-331.

Maddison, Wayne P., And D. R. Maddison. 1992. MacClade: Analysis of phylogeny and character evolution. Version 3.07. Sinauer Associates, Sunderland, MA.

McKenNa, M. C., AND S. K. Bell. 1997. Classification of mammals above the species level. Columbia University Press, New York, NY.

Miller, G. S. J. 1923. The telescoping of the cetacean skull. Smithsonian Miscellaneous Collections 76:1-71.

Noddle, B. 1974. Ages of epiphyseal closure in feral and domestic goats and ages of dental eruption. Journal of Archaeological Science 1:195-204.

Powell, R. J., AND G. R. Baum. 1982. Eocene biostratigraphy of South Carolina and its relationship to Gulf Coastal Plain zonations and global changes of coastal onlap. Geological Society of America Bulletin 93:1099-1108.

SWOFFord, D. L. 2000. PAUP*. Phylogenetic analysis using parsimony (*and other methods). Version 4.0b2a. Sinauer Associates, Sunderland, MA.

Thewissen, J. G. M., S. T. Hussain and M. Arif. 1994. Fossil evidence for the origin of aquatic locomotion in archaeocete whales. Science 263:210-212.

Thewissen, J. G. M., S. I. Madar and S. T. Hussain. 1996. Ambulocetus natans, an Eocene cetacean (Mammalia) from Pakistan. Courier Forschungsinstitut Senckenberg 191:1-86. 
Uhen, M. D. 1996. Dorudon atrox (Mammalia, Cetacea): Form, function, and phylogenetic relationships of an archaeocete from the Late Middle Eocene of Egypt. The University of Michigan, Ann Arbor, MI. 608 pp.

Uhen, M. D. 1998. Middle to Late Eocene Basilosaurines and Dorudontines. Pages 29-61 in J. G. M. Thewissen, ed. The emergence of whales. Plenum Press, New York. NY.

Yoshida, H., M. Shirakihara, A. Takemura and K. Shirakihara. 1994. Development, sexual dimorphism, and individual variation in the skeleton of the finless porpoise, Neophocaena phocaenoides, in the coastal waters of western Kyushu, Japan. Marine Mammal Science 10:266-282.

Zhou, X., W. J. Sanders and P. D. Gingerich. 1992. Functional and behavioral implications of vertebral structure in Pachyaena ossifraga (Mammalia, Mesonychia). Contributions from the Museum of Paleontology, University of Michigan 28:289319.

Received: 19 March 1999

Accepted: 10 April 2000 
Appendix 1. Character matrix used in stratocladistic analysis. Characters listed in first column. Character state codes described in Appendix 2. ? represents missing data. \& represents and. / represents or.

\begin{tabular}{|c|c|c|c|c|c|c|c|c|c|}
\hline & & $\begin{array}{l}\text { Dissa- } \\
\text { cus }\end{array}$ & $\begin{array}{l}P_{a-} \\
\text { cby- } \\
\text { aena }\end{array}$ & $\begin{array}{c}\text { Sino- } \\
n y x\end{array}$ & $\begin{array}{c}\text { Paki- } \\
\text { ce- } \\
\text { tus }\end{array}$ & $\begin{array}{l}\text { Ambu- } \\
\text { locetus }\end{array}$ & $\begin{array}{c}\text { Dal- } \\
\text { an- } \\
\text { istes }\end{array}$ & $\begin{array}{c}\text { Rem- } \\
\text { ing- } \\
\text { tonoce- } \\
\text { tus }\end{array}$ & $\begin{array}{l}\text { Rod- } \\
\text { bo- } \\
\text { cetus }\end{array}$ \\
\hline 1 & $\begin{array}{l}\text { frontal shield breadth rela- } \\
\text { tive to condylar breadth }\end{array}$ & 0 & 0 & 0 & $?$ & 0 & $?$ & 0 & 1 \\
\hline 2 & posterior frontal border & 0 & 0 & 0 & $?$ & 0 & 0 & 0 & 1 \\
\hline 3 & rostrum breadth & $?$ & ? & ? & ? & ? & 0 & 0 & 1 \\
\hline & $\begin{array}{l}\text { skull length relative to } \\
\text { condylar breadth }\end{array}$ & ? & $?$ & 0 & $?$ & $?$ & 2 & 2 & 1 \\
\hline 5 & embrasure pits & 0 & $?$ & 0 & $?$ & 1 & 1 & 1 & 1 \\
\hline 6 & $\begin{array}{l}\text { orbit height relative to } \\
\text { condylar breadth }\end{array}$ & 1 & 1 & 1 & $?$ & $?$ & 0 & 0 & 1 \\
\hline 7 & orbit position & 0 & 0 & 0 & $?$ & 2 & 0 & 0 & 0 \\
\hline 8 & palate narrows at & 1 & 1 & 1 & $?$ & 1 & 1 & 1 & 2 \\
\hline 9 & palate shape & 0 & 0 & 0 & $?$ & $?$ & 1 & 1 & 0 \\
\hline 10 & $\begin{array}{l}\text { falcate process of basioccip- } \\
\text { ital }\end{array}$ & 0 & 0 & 0 & 1 & 2 & 2 & 2 & 2 \\
\hline 11 & $\begin{array}{l}\text { vomer covers basioccipital/ } \\
\text { basisphenoid suture }\end{array}$ & 0 & 0 & 0 & 0 & $?$ & $?$ & $?$ & $?$ \\
\hline 12 & $\begin{array}{l}\text { large involucrum on tym- } \\
\text { panic bulla }\end{array}$ & 0 & 0 & 0 & 1 & 1 & $?$ & 1 & 1 \\
\hline 13 & $\begin{array}{l}\text { medial bulla articulation } \\
\text { with basioccipital }\end{array}$ & $?$ & $?$ & $?$ & 0 & 2 & ? & $?$ & 2 \\
\hline 14 & pterygoid sinus depth & 0 & 0 & 0 & 0 & 1 & 0 & 0 & 0 \\
\hline 15 & $\begin{array}{l}\text { lateral wall of pterygoid } \\
\text { sinus }\end{array}$ & 0 & 0 & 0 & 0 & 1 & $?$ & 0 & 0 \\
\hline 16 & $\begin{array}{l}\text { sigmoid process of tym- } \\
\text { panic bulla }\end{array}$ & 0 & 0 & 0 & 1 & 1 & $?$ & $?$ & 2 \\
\hline 17 & $\begin{array}{l}\text { hypoglossal foramen in } \\
\text { jugular notch }\end{array}$ & 0 & $?$ & 0 & 0 & 0 & $?$ & $?$ & 1 \\
\hline 18 & anterior palatine foramen & $?$ & $?$ & 1 & $?$ & $?$ & $?$ & 0 & 0 \\
\hline 19 & nuchal crest orientation & 0 & 0 & 0 & 0 & $?$ & $?$ & $?$ & 1 \\
\hline 20 & exoccipital shape & ? & $?$ & 0 & 1 & $?$ & 0 & 0 & 1 \\
\hline 21 & $\begin{array}{l}\text { position of posterior edge } \\
\text { of nares }\end{array}$ & 0 & 0 & 0 & $?$ & $?$ & 0 & 1 & 0 \\
\hline 22 & posterior nasal breadth & 2 & 2 & 2 & $?$ & 0 & 0 & 0 & $?$ \\
\hline 23 & $\begin{array}{l}\text { posterior medial maxilla } \\
\text { contacts }\end{array}$ & 1 & $?$ & 1 & $?$ & 0 & 0 & 0 & 0 \\
\hline 24 & mandibular foramen & 0 & 0 & 0 & 0 & 1 & $?$ & $?$ & 2 \\
\hline 25 & $\begin{array}{l}\text { mandibular symphysis po- } \\
\text { sition }\end{array}$ & 3 & 3 & 3 & 2 & 1 & 3 & 4 & 2 \\
\hline 26 & $\begin{array}{l}\text { mandibular symphysis } \\
\text { fused }\end{array}$ & 0 & 0 & 0 & 0 & $?$ & 0 & 1 & 0 \\
\hline 27 & incisors in tooth row & 0 & 0 & 0 & 1 & $?$ & 1 & 1 & 1 \\
\hline 28 & $\begin{array}{l}\text { cheek teeth with many } \\
\text { denticles }\end{array}$ & 0 & 0 & 0 & 0 & 0 & 0 & 0 & 0 \\
\hline 29 & number of $\mathrm{P}^{1}$ roots & 1 & 1 & 1 & $?$ & $?$ & 1 & 1 & $?$ \\
\hline 30 & number of upper molars & 3 & 3 & 3 & 3 & 3 & 3 & 3 & 3 \\
\hline & number of $\mathrm{M}^{1}$ roots & 0 & 0 & 0 & 0 & 0 & 0 & 0 & 0 \\
\hline $\begin{array}{l}32 \\
33\end{array}$ & number of $\mathrm{M}^{2}$ roots & 0 & 0 & 0 & 0 & 0 & 1 & 1 & $\begin{array}{l}0 \\
0\end{array}$ \\
\hline 35 & er 0 & 0 & 0 & 0 & 0 & 0 & 2 & 2 & 0 \\
\hline
\end{tabular}


Appendix 1. Extended.

\begin{tabular}{|c|c|c|c|c|c|c|c|c|c|c|c|}
\hline $\begin{array}{c}\text { Gavia- } \\
\text { cetus }\end{array}$ & Eocetus & $\begin{array}{c}\text { Babia- } \\
\text { cetus }\end{array}$ & $\begin{array}{c}\text { Geor- } \\
\text { gia- } \\
\text { cetus }\end{array}$ & $\begin{array}{c}\text { Proto- } \\
\text { cetus }\end{array}$ & $\begin{array}{l}\text { Basilo- } \\
\text { saurus }\end{array}$ & $\begin{array}{c}\text { Sagha- } \\
\text { cetus }\end{array}$ & $\begin{array}{l}\text { Zygo- } \\
\text { rbiza } \\
\end{array}$ & $\begin{array}{c}\text { Doru- } \\
\text { don }\end{array}$ & $\begin{array}{c}\text { Chryso- } \\
\text { cetus }\end{array}$ & $\begin{array}{c}\text { Odon- } \\
\text { to- } \\
\text { ceti }\end{array}$ & $\begin{array}{c}\text { Mysti- } \\
\text { ceti }\end{array}$ \\
\hline 2 & $?$ & $?$ & 0 & 2 & 2 & 2 & 2 & 2 & $?$ & 1 & 2 \\
\hline 1 & 1 & 1 & 1 & 1 & 1 & 1 & 1 & 1 & 1 & 2 & 2 \\
\hline 1 & 1 & 1 & 1 & 1 & 1 & 1 & 1 & 1 & 1 & 1 & 3 \\
\hline$?$ & $?$ & $?$ & $?$ & 1 & 2 & 0 & 1 & 1 & $?$ & 0 & 0 \\
\hline 1 & 1 & 1 & 1 & 1 & 1 & 1 & 1 & 1 & 1 & 0 & 0 \\
\hline$?$ & $?$ & $?$ & 1 & $?$ & 1 & 1 & 1 & 1 & $?$ & $?$ & $?$ \\
\hline 0 & 0 & 0 & 0 & 0 & 0 & 0 & 0 & 0 & 0 & 0 & 0 \\
\hline$?$ & $?$ & 3 & 1 & 2 & 4 & 4 & 3 & 4 & $?$ & 0 & 0 \\
\hline 0 & $?$ & 0 & 0 & 0 & 0 & 0 & 0 & 0 & $?$ & $\begin{array}{c}0 \& 1 \\
\& 2\end{array}$ & 2 \\
\hline 1 & $?$ & 2 & 2 & 2 & 2 & 2 & 2 & 2 & $?$ & 2 & 2 \\
\hline 1 & $?$ & $?$ & 1 & $?$ & 1 & 1 & 1 & 1 & $?$ & $0 / 1$ & 0 \\
\hline 1 & $?$ & 1 & $?$ & 1 & 1 & 1 & 1 & 1 & 1 & 1 & 1 \\
\hline 1 & $?$ & 2 & 1 & $?$ & 2 & 2 & 2 & 2 & $?$ & 2 & 2 \\
\hline 0 & 0 & 0 & 1 & 0 & 2 & 2 & 2 & 2 & $?$ & 2 & 2 \\
\hline$?$ & $?$ & 0 & 1 & 0 & 1 & 1 & 1 & 1 & $?$ & 1 & 1 \\
\hline 2 & $?$ & 2 & 2 & 2 & 2 & 2 & 2 & 2 & 2 & 2 & 2 \\
\hline 1 & $?$ & 1 & 1 & 1 & 1 & 1 & 1 & 1 & $?$ & 1 & 1 \\
\hline$?$ & 0 & $?$ & 0 & $?$ & 0 & 0 & 0 & 0 & $?$ & 0 & 0 \\
\hline 0 & $?$ & $?$ & 0 & 1 & 2 & 2 & 2 & 2 & 2 & 3 & 3 \\
\hline 1 & $?$ & $?$ & 1 & 1 & 1 & 1 & 1 & 1 & $?$ & 1 & 1 \\
\hline$?$ & 1 & 1 & 1 & 1 & 1 & 2 & 2 & 2 & $?$ & 3 & 3 \\
\hline 2 & $?$ & 2 & 1 & 0 & 0 & 0 & 0 & 0 & $?$ & 3 & 3 \\
\hline 0 & $?$ & 0 & 0 & 0 & 0 & 1 & 1 & 0 & $?$ & $0 \& 1$ & 2 \\
\hline$?$ & $?$ & 2 & 2 & $?$ & 2 & 2 & 2 & 2 & 2 & 2 & 2 \\
\hline$?$ & $?$ & 2 & 2 & $?$ & 2 & 2 & 2 & 2 & $?$ & 1 & 1 \\
\hline$?$ & $?$ & 1 & 0 & $?$ & 0 & 0 & 0 & 0 & $?$ & $0 \& 1$ & 0 \\
\hline$?$ & 1 & 1 & 1 & 1 & 1 & 1 & 1 & 1 & 1 & 1 & 1 \\
\hline 0 & 0 & 0 & 1 & 0 & 2 & 2 & 2 & 2. & 2 & 2 & 2 \\
\hline$?$ & 2 & 2 & 2 & 2 & 1 & 1 & 2 & 1 & 1 & $?$ & $?$ \\
\hline 3 & $2 / 3$ & 3 & 3 & 3 & 2 & 2 & 2 & 2 & $?$ & $?$ & $?$ \\
\hline 0 & 0 & 0 & 1 & 0 & 2 & 2 & 2 & 2 & $?$ & $?$ & $?$ \\
\hline 0 & $?$ & 0 & 1 & 0 & 2 & 2 & 2 & 2 & $?$ & $?$ & $?$ \\
\hline$?$ & $?$ & 0 & 1 & 1 & $?$ & $?$ & $?$ & $?$ & $?$ & $?$ & $?$ \\
\hline
\end{tabular}


Appendix 1. Continued.

\begin{tabular}{|c|c|c|c|c|c|c|c|c|c|}
\hline & & $\begin{array}{c}\text { Dissa- } \\
\text { cus }\end{array}$ & $\begin{array}{l}P a- \\
c b y- \\
\text { aena }\end{array}$ & $\begin{array}{l}\text { Sino- } \\
n y x\end{array}$ & $\begin{array}{c}\text { Paki- } \\
c e- \\
\text { tus }\end{array}$ & $\begin{array}{l}\text { Ambu- } \\
\text { locetus }\end{array}$ & $\begin{array}{c}\text { Dal- } \\
\text { an- } \\
\text { istes }\end{array}$ & $\begin{array}{c}\text { Rem- } \\
\text { ing- } \\
\text { tonoce- } \\
\text { tus }\end{array}$ & $\begin{array}{l}\text { Rod- } \\
\text { bo- } \\
\text { cetus }\end{array}$ \\
\hline 34 & tooth replacement & 0 & $\overline{0}$ & 0 & 0 & ? & ? & $?$ & $?$ \\
\hline 35 & number of $P_{1}$ roots & 1 & 1 & 1 & 1 & 2 & $\dot{2}$ & $\dot{2}$ & 2 \\
\hline 36 & $\begin{array}{l}\text { reentrant groove on lower } \\
\text { molar }\end{array}$ & 0 & 0 & 0 & 1 & 1 & 1 & $\overline{1}$ & 1 \\
\hline 37 & $\begin{array}{l}\text { cervical vertebrae com- } \\
\text { pressed }\end{array}$ & $?$ & 0 & 0 & $?$ & 0 & $?$ & 0 & 1 \\
\hline 38 & number of thoracics & ? & 1 & 1 & $?$ & $?$ & $?$ & $?$ & 1 \\
\hline 39 & number of lumbars & $?$ & 0 & 0 & ? & $\dot{0}$ & 0 & ; & 0 \\
\hline 40 & lumbars elongate & ? & 0 & 0 & ? & 0 & $?$ & ? & 0 \\
\hline 41 & lumbar zygapophyses & $?$ & 0 & 0 & $?$ & 1 & $?$ & $?$ & 1 \\
\hline 42 & $\begin{array}{l}\text { number of sacrals solidly } \\
\text { ankylosed }\end{array}$ & $?$ & 3 & 3 & $?$ & $?$ & 4 & 4 & 1 \\
\hline 43 & $\begin{array}{l}\text { number of sacrals loosely } \\
\text { joined }\end{array}$ & $?$ & 1 & 1 & $?$ & $?$ & 1 & 1 & 4 \\
\hline 44 & $\begin{array}{l}\text { number of sacrals articu- } \\
\text { late with pelvis }\end{array}$ & $?$ & 1 & 1 & $?$ & $?$ & 2 & 2 & 1 \\
\hline 45 & $\begin{array}{l}\text { posterior caudals dorsoven- } \\
\text { trally compressed }\end{array}$ & $?$ & 0 & 0 & $?$ & $?$ & ? & $?$ & $?$ \\
\hline 46 & anterior caudals elongate & $?$ & 1 & 1 & $?$ & 1 & 1 & 1 & 0 \\
\hline 47 & posterior caudals elongate & ? & 1 & 1 & $?$ & ? & $?$ & ? & ? \\
\hline 48 & $\begin{array}{l}\text { infraspinous fossa on scap- } \\
\text { ula }\end{array}$ & $?$ & 0 & 0 & $?$ & $?$ & $?$ & $?$ & $?$ \\
\hline 49 & $\begin{array}{l}\text { coracoid process oriented } \\
\text { anteriorly }\end{array}$ & $?$ & 0 & 0 & $?$ & $?$ & $?$ & $?$ & $?$ \\
\hline 50 & $\begin{array}{l}\text { acromion process oriented } \\
\text { anteriorly }\end{array}$ & $?$ & 0 & 0 & ? & $?$ & $?$ & $?$ & $?$ \\
\hline 51 & $\begin{array}{l}\text { humeral shaft anteroposte- } \\
\text { riorly thick }\end{array}$ & 0 & 0 & 0 & $?$ & $?$ & $?$ & $?$ & $?$ \\
\hline 52 & deltopectoral crest position & $?$ & 0 & 0 & $?$ & $?$ & ? & $?$ & $?$ \\
\hline 53 & $\begin{array}{l}\text { distal humeral articulation } \\
\text { divided }\end{array}$ & 1 & 1 & 1 & $?$ & $?$ & $?$ & $?$ & $?$ \\
\hline 54 & radius and ulna flat & 0 & 0 & 0 & $?$ & 0 & ? & ? & ? \\
\hline 55 & broad olecranon process & 0 & 0 & 0 & $?$ & 1 & $?$ & $?$ & ? \\
\hline 56 & distal ulna & 0 & 0 & 0 & ? & 0 & ? & ? & ? \\
\hline 57 & $\begin{array}{l}\text { saddle-shaped carpal artic- } \\
\text { ular surfaces }\end{array}$ & 1 & 1 & 1 & ? & 1 & ? & ? & ? \\
\hline 58 & trapezoid and magnum & 0 & 0 & 0 & ? & 0 & ? & $?$ & $?$ \\
\hline 59 & carpals in alternating rows & 1 & 1 & 1 & $?$ & 0 & $?$ & $?$ & $?$ \\
\hline 60 & pisiform & ? & 1 & 1 & $?$ & 2 & $?$ & $?$ & $?$ \\
\hline 61 & hyperphalangy & 0 & 0 & 0 & ? & 0 & $?$ & $?$ & $?$ \\
\hline 62 & pelvis & 3 & 3 & 3 & $?$ & $?$ & 3 & 3 & 3 \\
\hline 63 & pelvis rotation & 0 & 0 & 0 & $?$ & $?$ & 0 & 0 & 0 \\
\hline 64 & femur & 4 & 4 & 4 & $?$ & 4 & 4 & 4 & 3 \\
\hline 65 & tarsals & 0 & 0 & 0 & ? & 0 & $?$ & ? & $?$ \\
\hline 66 & tibia/fibula & 0 & 0 & 0 & $?$ & 0 & $?$ & 0 & $?$ \\
\hline 67 & sternum form & ? & 0 & 0 & $?$ & $?$ & ? & ? & 1 \\
\hline 68 & body size & 0 & 0 & 0 & 0 & 2 & 2 & 2 & 1 \\
\hline 69 & stratigraphic position & $0 \& 1$ & $1 \& 2$ & 0 & 2 & 2 & 4 & $\begin{array}{c}4 \& \\
5 \& 6\end{array}$ & 3 \\
\hline
\end{tabular}


Appendix 1. Continued. Extended.

\begin{tabular}{|c|c|c|c|c|c|c|c|c|c|c|c|}
\hline $\begin{array}{c}\text { Gavia- } \\
\text { cetus }\end{array}$ & Eocetus & $\begin{array}{c}\text { Babia- } \\
\text { cetus. }\end{array}$ & $\begin{array}{l}\text { Geor- } \\
\text { gia- } \\
\text { cetus }\end{array}$ & $\begin{array}{l}\text { Proto- } \\
\text { cetus }\end{array}$ & $\begin{array}{l}\text { Basilo- } \\
\text { saurus }\end{array}$ & $\begin{array}{l}\text { Sagha- } \\
\text { cetus }\end{array}$ & $\begin{array}{l}\text { Zygo- } \\
\text { rbiza }\end{array}$ & $\begin{array}{c}\text { Doru- } \\
\text { don }\end{array}$ & $\begin{array}{c}\text { Chryso- } \\
\text { cetus }\end{array}$ & $\begin{array}{l}\text { Odon- } \\
\text { to- } \\
\text { ceti }\end{array}$ & $\begin{array}{c}\text { Mysti- } \\
\text { ceti }\end{array}$ \\
\hline$?$ & ? & ? & ? & $?$ & 0 & 0 & 0 & 0 & 1 & 2 & 2 \\
\hline$?$ & 2 & 2 & 2 & $?$ & 1 & 1 & 2 & 2 & 1 & ? & ? \\
\hline$?$ & $?$ & 1 & 1 & $?$ & 1 & 1 & 1 & 1 & $?$ & 1 & $?$ \\
\hline$?$ & ? & ? & 1 & 2 & 2 & 2 & 2 & 2 & 2 & 2 & 2 \\
\hline ? & ? & ? & 1 & 2 & 2 & 2 & 2 & 2 & 2 & 3 & 3 \\
\hline ? & ? & $?$ & 0 & 0 & 2 & 2 & 2 & 2 & $?$ & 2 & 2 \\
\hline ? & 1 & $?$ & 0 & 0 & 2 & 1 & 0 & 0 & 0 & 0 & 0 \\
\hline$?$ & 2 & $?$ & 2 & 2 & 2 & 2 & 2 & 2 & 2 & 3 & 3 \\
\hline$?$ & ? & $?$ & 1 & 1 & 1 & 1 & 1 & 1 & $?$ & 1 & 1 \\
\hline$?$ & $?$ & $?$ & 1 & 1 & 1 & 1 & 1 & 1 & $?$ & 1 & 1 \\
\hline$?$ & ? & $?$ & 0 & 1 & 0 & 0 & 0 & 0 & 0 & 0 & 0 \\
\hline ? & $?$ & $?$ & $?$ & $?$ & 1 & $?$ & 1 & 1 & $?$ & 1 & 1 \\
\hline$?$ & ? & $?$ & 0 & $?$ & 1 & $?$ & 0 & 0 & ? & 0 & 0 \\
\hline$?$ & $?$ & $?$ & $?$ & $?$ & 0 & $?$ & 0 & 0 & $?$ & 0 & 0 \\
\hline$?$ & $?$ & $?$ & $?$ & $?$ & 2 & $?$ & 2 & 2 & 2 & 2 & 2 \\
\hline$?$ & $?$ & $?$ & $?$ & $?$ & 1 & $?$ & 1 & 1 & 1 & 1 & 1 \\
\hline$?$ & $?$ & $?$ & $?$ & $?$ & 1 & $?$ & 1 & 1 & 1 & 1 & 1 \\
\hline$?$ & $?$ & $?$ & $?$ & $?$ & 1 & $?$ & 1 & 1 & 1 & 1 & 1 \\
\hline$?$ & $?$ & $?$ & $?$ & $?$ & 2 & $?$ & 1 & 2 & 1 & 0 & 0 \\
\hline$?$ & $?$ & $?$ & $?$ & $?$ & 0 & $?$ & 0 & 0 & 0 & 0 & 0 \\
\hline ? & $?$ & ? & $?$ & ? & 1 & ? & 1 & 1 & 1 & 1 & 1 \\
\hline$?$ & $?$ & $?$ & $?$ & $?$ & 1 & $?$ & 1 & 1 & 1 & 1 & 1 \\
\hline$?$ & $?$ & $?$ & $?$ & $?$ & 1 & $?$ & 1 & 1 & 1 & 1 & 1 \\
\hline$?$ & $?$ & $?$ & $?$ & $?$ & 0 & $?$ & 0 & 0 & 0 & 0 & 0 \\
\hline ? & $?$ & $?$ & ? & ? & 1 & ? & 1 & 1 & $?$ & 1 & 1 \\
\hline$?$ & $?$ & $?$ & $?$ & $?$ & 1 & $?$ & 1 & 1 & $?$ & 1 & 1 \\
\hline$?$ & $?$ & $?$ & $?$ & $?$ & 2 & $?$ & 2 & 2 & $?$ & $?$ & $?$ \\
\hline$?$ & ? & $?$ & $?$ & $?$ & 0 & $?$ & 0 & 0 & $?$ & 1 & 1 \\
\hline$?$ & 2 & $?$ & 3 & ? & 1 & $?$ & $?$ & $?$ & 1 & 0 & 0 \\
\hline$?$ & 0 & $?$ & 0 & ? & 1 & $?$ & $?$ & $?$ & 1 & 1 & 1 \\
\hline$?$ & $?$ & $?$ & $?$ & $?$ & 2 & $?$ & $?$ & 2 & $?$ & 0 & 1 \\
\hline$?$ & $?$ & $?$ & $?$ & $?$ & 1 & $?$ & $?$ & $?$ & $?$ & ? & $?$ \\
\hline$?$ & $?$ & $?$ & $?$ & $?$ & 1 & $?$ & $?$ & $?$ & $?$ & $?$ & $?$ \\
\hline$?$ & $?$ & $?$ & $0 \& 1$ & $?$ & 1 & 1 & 1 & 1 & 1 & 2 & 2 \\
\hline 1 & 2 & 2 & 2 & 2 & 3 & 1 & 2 & 2 & 2 & $\begin{array}{l}0 \& \\
1 \&\end{array}$ & $\begin{array}{c}1 \& \\
2 \& 3\end{array}$ \\
\hline 4 & 6 & 6 & 6 & 4 & 788 & 8 & 8 & $7 \& 8$ & 7 & $\begin{array}{c}2 \& 3 \\
\mathrm{~A}\end{array}$ & A \\
\hline
\end{tabular}


Appendix 2. Characters and character states used in data matrix in Appendix 1 . Zero not necessarily primitive state for character codes.

1. frontal shield breadth relative to condylar breadth

$$
\begin{aligned}
& 0:<2 \\
& 1:>2<2.5 \\
& 2:>2.5
\end{aligned}
$$

2. posterior frontal border

$$
\begin{aligned}
& 0: \text { angled back } \\
& \text { 1: straight } \\
& 2 \text { : curved }
\end{aligned}
$$

3. rostrum breadth

$$
\begin{aligned}
& \text { 0: narrow } \\
& \text { 1: moderate } \\
& \text { 2: broad } \\
& \text { 3: very broad }
\end{aligned}
$$

4. skull length relative to condylar breadth
$0:<7$
$1: 7-8$

$$
\text { 2: }>8
$$

5. embrasure pits

0 : absent

1: present

6. orbit height relative to condylar breadth

$$
\begin{aligned}
& 0:<0.3 \\
& 1:>0.3
\end{aligned}
$$

7. orbit position
0 : low
1: moderate
2: high

8. palate narrows at

0: posterior to $\mathrm{M}^{3}$

1: $\mathrm{M}^{3}$

2: $\mathbf{M}^{2}$

3: $\mathbf{M}^{1}$

4: $\mathrm{P}^{4}$

9. palate shape
0 : flat
1: convex
2: concave

10. falcate process of basioccipital

0 : absent

1: small

2: large

11. vomer covers basioccipital/basisphenoid suture

0 : no

1: yes

12. large involucrum on tympanic bulla 0 : absent

1: present
13. medial bulla articulation with basioccipital
0 : broad
1: short
2: absent

14. pterygoid sinus depth
0: absent
1: shallow
2: present

15. lateral wall of pterygoid sinus

0 : absent

1: present

16. sigmoid process of tympanic bulla
0 : absent
1: small
2: large

17. hypoglossal foramen in jugular notch 0 : no

1: yes

18. anterior palatine foramen

$$
0 \text { : absent }
$$

1: present

19. nuchal crest orientation

0: greatly angled back

1: slightly angled back

2: vertical

3: reduced or absent

20. exoccipital shape

$$
\begin{aligned}
& 0: \text { angled } \\
& 1: \text { squared }
\end{aligned}
$$

21. position of posterior edge of nares

0 : level with $\mathrm{C}^{1}$

1: level with $\mathbf{P}^{1}$

2: level with $\mathrm{P}^{2}$

3: posterior to $\mathrm{P}^{2}$

22. posterior nasal breadth
0 : narrow
1: moderate
2: broad
3: reduced

23. posterior medial maxilla contacts
0 : nasal
1: frontal
2: premaxilla

24. mandibular foramen
0: small
1: moderate
2: large

25. mandibular symphysis position

1: level with $P_{1}$ or more anterior 2: level with $\mathrm{P}_{2}$ 
Appendix 2. Continued.
3: level with $P_{3}$
4: level with $\mathrm{P}_{4}$
$0:<10$
1: $10-15$
2: $>15$

26. mandibular symphysis fused

0 : no

1: yes

27. incisors in tooth row

$0:$ no

$1:$ yes

28. cheek teeth with many denticles

0 : no

1: incipient

2: yes

29. number $\mathrm{P}^{1}$ roots

1: one

2: two

30. number of upper molars
0 : none
1: one
2: two
3: three

31. number of $\mathbf{M}^{1}$ roots

0 : three

1: incipient 3

2: two

32. number of $\mathrm{M}^{2}$ roots

0 : three

1: incipient 3

2: two

33. number of $\mathbf{M}^{3}$ roots

0 : three

1: incipient 3

2: two

34. tooth replacement

0 : diphyodont

1: accelerated adult eruption

2: monophyodont

35. number of $P_{1}$ roots
1: one

2: two

36. reentrant groove on lower molars

0 : absent

1: present

37. cervical vertebrae compressed
0 : none
1: moderate
2: a lot

38. number of thoracics
$0:<10$
1: $10-15$
2: $15-20$
3: $>20$

39. number of lumbars

40. lumbars elongate
0 : no
1: moderate
2: considerably

41. lumbar zygapophyses
0 : revolute
1: curved
2: flat
3: absent

42. number of sacrals solidly ankylosed
1: none
2: two
3: three
4: four

43. number of sacrals loosely joined
1: none
2: two
3: three
4: four

44. number of sacrals articulate with pelvis
0 : none
1: one
2: two
3: three
4: four

45. posterior caudals dorsoventrally compressed

0 : no

1: yes

46. anterior caudals elongate

0 : no

1: yes

47. posterior caudals elongate
0 : no
1 : yes

48. infraspinous fossa on scapula
0 : small
1: moderate
2: large

49. coracoid process oriented anteriorly

0 : no

1 : yes

50. acromion process oriented anteriorly

$0:$ no

$1:$ yes

2: folded back

51. humeral shaft anteroposteriorly thick 0 : no 
Appendix 2. Continued.

\begin{tabular}{|c|c|}
\hline 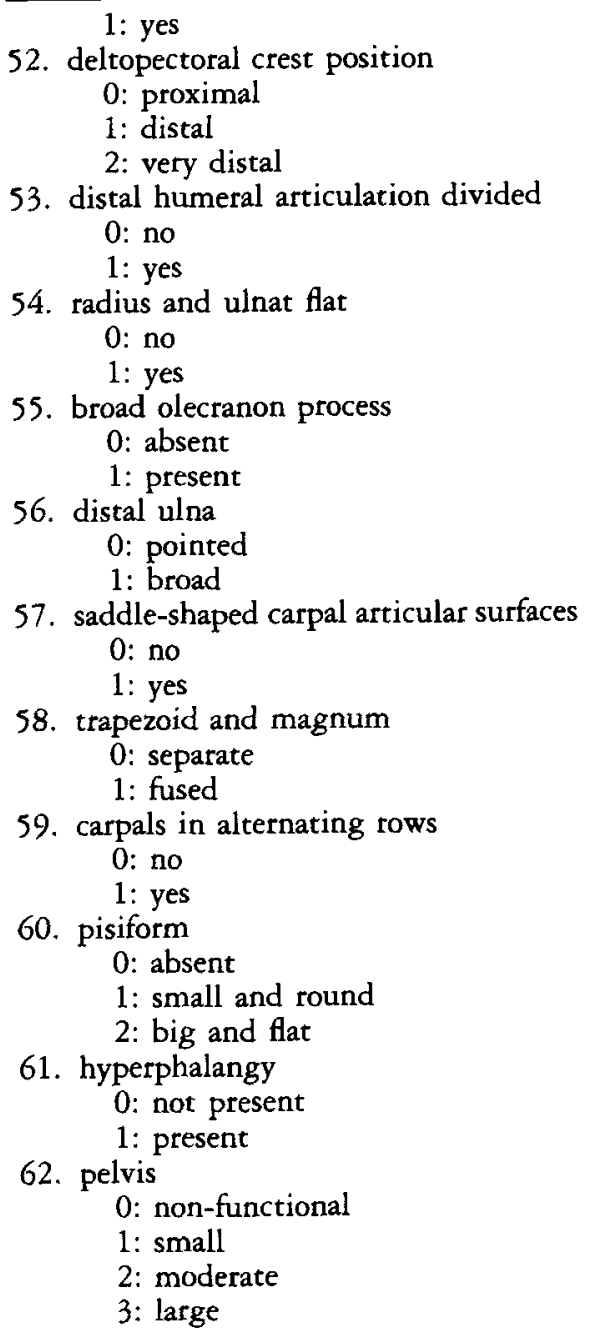 & $\begin{array}{l}\text { 63. pelvis rotation } \\
\text { 0: no } \\
\text { 1: yes } \\
\text { 64. femur } \\
\text { 0: absent } \\
\text { 1: non-functional } \\
\text { 2: small } \\
\text { 3: moderate } \\
\text { 4: large } \\
\text { 65. tarsals } \\
\text { 0: separate } \\
\text { 1: fused } \\
\text { 66. tibia/fibula } \\
\text { 0: separate } \\
\text { 1: fused } \\
\text { 67. sternum form } \\
0: \text { rod-like } \\
\text { 1: big and heavy } \\
\text { 2: flat and light } \\
\text { 68. body size } \\
\text { 0: small } \\
\text { 1: moderate } \\
\text { 2: large } \\
\text { 3: very large } \\
\text { 69. stratigraphic position } \\
\text { 0: Thanetian } \\
\text { 1: early Ypresian } \\
\text { 2: latest Ypresian } \\
\text { 3: early Lutetian } \\
\text { 4: middle Lutetian } \\
\text { 5: late Lutetian } \\
\text { 6: early Bartonian } \\
\text { 7: late Bartonian } \\
\text { 8: early Priabonian } \\
\text { 9: late Priabonian } \\
\text { A: post Priabonian }\end{array}$ \\
\hline
\end{tabular}

